\title{
THE DISCURSIVE USE AND DEVELOPMENT OF THE GUIDING PRINCIPLES ON BUSINESS AND HUMAN RIGHTS IN LATIN AMERICA*
}

\author{
EL DESARROLLO Y USO DISCURSIVO DE LOS \\ PRINCIPIOS RECTORES SOBRE EMPRESAS Y \\ DERECHOS HUMANOS EN AMÉRICA LATINA
}

\author{
Nicolás Carrillo-Santarelli** \\ Carlos Arévalo-NarváeZ***
}

Fecha de recepción: 30 de abril de 2017

Fecha de aceptación: 15 de mayo de 2017

Disponibilidad en linea: 30 de junio de 2017

\section{Para Citar Este Artículo / To Cite This Article}

Carrillo-Santarelli, Nicolás \& Arévalo-Narváez, Carlos, The Discursive use and Development of the Guiding Principles on Business and Human Rights in Latin America, 30 International Law, Revista Colombiana de Derecho Internacional, 61-118(2017). https://doi.org/10.11144/Javeriana.il 15-30.dudg

doi:10.11144/Javeriana.i115-30.dudg

* Este artículo de investigación es el producto de estudios conjuntos realizados por los dos autores en la Universidad de La Sabana, en el marco del grupo de investigación en Derecho Internacional.

** Profesor e investigador en Derecho Internacional de la Universidad de La Sabana. Doctor en Derecho Internacional y Relaciones Internacionales por la Universidad Autónoma de Madrid. Máster en Protección de los Derechos Humanos por la Universidad de Alcalá. Abogado por la Universidad Externado de Colombia. Contacto: nicolas.carrillos@gmail.com

*** Jefe del Departamento de Derecho Internacional de la Universidad de La Sabana. Magíster en Derecho Internacional (LL.M. in International Legal Studies) por la Universidad de Nueva York (NYU). Abogado por la Universidad de La Sabana. Contacto: carlos.arevalo1@unisabana. edu.co 


\section{RESUMEN}

Como consecuencia de su amplia aceptación, los Principios Rectores sobre Empresas y Derechos Humanos se han erigido en el principal referente normativo en la materia. Ello explica que, gracias a sus efectos expresivos, hayan permeado e influido en la forma como diferentes actores presenten sus discursos. Al apropiarse de los conceptos que en ellos se encuentran, tanto los Estados como los órganos supervisores, los activistas y las propias empresas en América Latina pueden o bien invocarlos para fortalecer iniciativas que buscan mejorar la protección contra abusos empresariales o abstenerse de ir más allá de lo que los Principios dicen. Este artículo estudia cómo se han presentado estas dinámicas en América Latina y analiza la jurisprudencia de la Comisión y Corte Interamericanas de Derechos Humanos, planes de acción nacional y otras iniciativas estatales en la región y si ha habido pronunciamientos de empresas que operan en la región que se hayan referido a los Principios.

Palabras clave: principios rectores sobre empresas y derechos humanos; internalización; participantes en el derecho internacional; aproximación política al derecho internacional; derechos humanos 


\section{ABSTRACT}

Due to their widespread acceptance, the Guiding Principles on Business and Human Rights are currently the main normative body of reference in the field, and so, given their expressive functions, they permeate and determine the way in which different actors shape their discourses. By appropriating the conceptsfound therein, States, supervisorybodies, activists, andbusinesses in the Americas can either invoke the Guiding Principles to strengthen initiatives aimed at enhancing protection from corporate abuses or refrain from going beyond what they say. This article studies how those dynamics have been present in the Americas, by exploring the case law of the Inter-American Court and Commission on Human Rights, national action plans, and other State initiatives in the region, and whether corporate statements of businesses operating in the region have referred to the Principles.

Keywords: Guiding Principles on Business and Human Rights; internalization; participants in international law; policy approach to international law; human rights

SumARIO

INTRODUCTION. I. THE GUIDING PRINCIPLES AS A VERNACULAR APPROPRIATED BY PARTICIPANTS THAT CAN HAVE SYNERGY WITH PROGRESSIVE DEVELOPMENT OR CONSERVATIVE APPROACHES. A. The Appropriation of the Language Of The UNGPS by Regional Actors. B. The Propelling or Halting Developments as a Result Of The Internalization Of The Language Of The Guiding Principles On Business And Human Rights- II. DEVELOPMENTS AND RESPONSES CONCERNING BUSINESS AND HUMAN RIGHTS ISSUES BY THE INTER-AMERICAN COMMISSION AND COURT OF HUMAN RIGHTS. A. Engagement Of The Main Bodies Of The Inter-American Human Rights System With Business And Human Rights Issues Before The 2011 Adoption Of The Guiding Principles. B. Examination Of Corporate Participation In Abuses In The Inter-American Human Rights System Since The Adoption Of The Guiding Principles On Business And Human Rights In 2011. III. THE INFLUENCE OF THE GUIDING PRINCIPES ON BUSINESS ANDHUMANRIGHTSINTHEACTIONS AND MINDSET OF STATES IN THE AMERICAS AND BUSINESSES OPERATING THEREIN. A. The Use And Invocation Of The Guiding Principles On Business And Human Rights By Judicial Authorities In The Americas. B. The Guiding Principles As The Inspiration Of Developments Of Legislative State Action And Policies In The Americas. C. Reference To The Guiding Principles In The Codes Of Conduct Of Corporations That Operate In The Americas. CONCLUSIONS. BIBLIOGRAPHY 
INTRODUCTION

The adoption in 2011 of the United Nations Guiding Principles on Business and Human Rights, which in turn render operative and develop the "Protect, Respect, and Remedy" Framework drafted by former Special Representative of the Secretary-General on human rights and transnational corporations and other business enterprises John Ruggie, ${ }^{1}$ are widely regarded as a milestone in the normative process towards the protection of individuals from corporate abuses. This is so, considering prior failed attempts at drafting standards on the subject ${ }^{2}$ and the previous lack of a unified normative body addressing the human rights dimensions of corporate activities and protection from their negative impacts on their enjoyment.

Nevertheless, the Guiding Principles (hereinafter, UNGPs or the Guiding Principles) themselves have not been regarded as the final step in the aforementioned process for a variety of reasons, including the fact that the corporate "respect" pillar of the Principles is not considered to necessarily envisage direct corporate international legal obligations to respect human rights. While John Ruggie himself, and authors such as Jernej Letnar, consider that the Principles do not foreclose the possibility of the appearance of international legal obligations of businesses, such as those related to refraining from participating in or as-

1 In this regard, it has been said that "[i]n 2011, the UN Human Rights Council unanimously endorsed the UN Guiding Principles on Business and Human Rights, a set of guidelines that operationalize the UN Framework and further define the key duties and responsibilities of States and business enterprises with regard to business-related human rights abuses", as mentioned in: United Nations Working Group on Business and Human Rights, The UN Guiding Principles on Business and Human Rights: An Introduction, at 2. http:/www.ohchr.org/Documents/Issues/ Business/Intro_Guiding_PrinciplesBusinessHR.pdf

2 United Nations, The UN "Protect, Respect and Remedy" Framework for Business and Human Rights, 2010, at 1. https://business-humanrights.org/sites/default/files/reports-and-materials/ Ruggie-protect-respect-remedy-framework.pdf. There, it is explained how "[i]n 2004, the Sub-commission of the then UN Commission on Human Rights produced a set of "Draft Norms on the Responsibilities of Transnational Corporations and Other Business Enterprises with Regard to Human Rights [...] Business was vehemently opposed to the Draft Norms, some human rights advocacy groups strongly in favor. The Commission on Human Rights declined to adopt the document." 
sisting international crimes or violations of peremptory law; ${ }^{3}$ the UNGPs themselves indicate in Commentary to Principle 12 that:

[t]he responsibility of business enterprises to respect human rights is distinct from issues of legal liability and enforcement, which remain defined largely by national law provisions in relevant jurisdictions. ${ }^{4}$

This is problematic insofar as State obligations to protect from corporate misdeeds are duties of conduct. Thus, there may be corporate violations that engage no State responsibility, and in which businesses elude jurisdictional controls. This may happen when, among others, they "jump from one jurisdiction to another," as commented by the open-ended intergovernmental working group on transnational corporations and other business enterprises with respect to human rights, with the mandate of elaborating an internationally legally-binding instrument. ${ }^{5}$ In those events, given an absent clarity on the legal scope of extraterritorial State obligations, victims may end up with no effective access to remedies and corporate abuses might remain in impunity. This may occur because, since State and corporate responsibilities are different, it may happen that a corporation perpetrates or contributes to an abuse, but the State's responsibility is not engaged because it did not breach obligations of its own, for instance, because it diligently strived (but failed) to prevent or respond to the abuse.

Because of this, some States, academics, and members of civil society, have come up with proposals of adopting complementary

3 According to John H. Knox, John Ruggie considered that "with the potential exceptions of "the most heinous human rights violations amounting to international crimes, including genocide, slavery, human trafficking, forced labor, torture, and some crimes against humanity," human rights law does not currently impose direct obligations on corporations or any other non-state actors," as explained in: John H. Knox, The Human Rights Council Endorses "Guiding Principles” for Corporations, 15 ASIL Insights, 2011. Additionally, see: John G. Ruggie, Kiobel and Corporate Social Responsibility: An Issues Brief by John G. Ruggie. (Harvard Kennedy School. John F. Kennedy School of Government, 2012).

4 United Nations, Guiding Principles on Business and Human Rights: Implementing the United Nations "Protect, Respect and Remedy" Framework, 2011, at 14.

5 Human Rights Council, Report on the first session of the open-ended intergovernmental working group on transnational corporations and other business enterprises with respect to human rights, with the mandate of elaborating an internationally legally binding instrument, $A / H R C / 31 / 50,5$ February 2016, para. 50. 
standards that do not deny, but rather acknowledge and build on, the UNGPs. Such standards may be either contained in a treaty or in an alternative instrument or source -be it a Declaration, as Surya Deva has suggested, or the progressive development of customary law. ${ }^{6}$ That being said, the eventual regulation of direct corporate duties via the adoption of such an instrument is still uncertain in political terms, and some have debated its benefits. ${ }^{7}$

In this context, Latin American States and societies find themselves in a conundrum, given the sporadic or more frequent occurrence of worrisome corporate human rights abuses in some of them, including some perpetrated in the context of armed conflict, as in the Colombian scenario. It is no coincidence, after all, that along with South Africa, it was Ecuador, a State of the Americas that has experienced the difficulties of bringing transnational or other corporate misdeeds to justice, the one to advance the proposal of negotiating a treaty on business and human rights. ${ }^{8}$

In the absence of hard law international standards on corporate human rights responsibility, it is worth asking if the domestic and regional authorities in the Americas have relied on and invoked the UNGPs. Be it either to support and reinforce previous efforts of protection, or to initiate new actions aimed at safeguarding potential victims from corporate abuses and

6 Surya Deva, 'What if the Roadblock Continues?': Alternatives Ways to Getting a Business and Human Rights Treaty, in The Future of Business and Human Rights: Theoretical and Practical Considerations for a UN Treaty (Jernej Letnar Černič and Nicolás Carrillo-Santarelli, (eds.), Intersentia, Cambridge, Forthcoming 2017); Nicolás Carrillo-Santarelli, Inconvenient and Unnecessary? A Defense of Direct International Human Rights Obligations of (All) Corporations, in The Future of Business and Human Rights: Theoretical and Practical Considerations for a UN Treaty (Jernej Letnar Černič and Nicolás Carrillo-Santarelli, eds., Intersentia, Cambridge Forthcoming 2017).

7 Surya Deva, op. cit.; Tara L. Van Ho, ““Say You'll Remember Me:” In Defense of a Traditional State-Centric Approach to the Treaty", in The Future of Business and Human Rights: Theoretical and Practical Considerations for a UN Treaty (Jernej Letnar Černič and Nicolás Carrillo-Santarelli, eds., Intersentia, Cambridge, Forthcoming 2017).

8 Source: https://business-humanrights.org/en/binding-treaty; Human Rights Council, Elaboration of an international legally binding instrument on transnational corporations and other business enterprises with respect to human rights, A/HRC/26/L.22/Rev.1, 25 June 2014; Business \& Human Rights Resource Centre, Texaco/Chevron lawsuits (re Ecuador). https:// business-humanrights.org/en/texacochevron-lawsuits-re-ecuador 
treating the latter as wrongful acts under their jurisdiction or in the region.

That question is of the utmost relevance, considering the relative economic weakness of Latin American societies vis-a-vis influential multinational groups and transnational corporations and investors. This may lead to a lowering of Standards in a raceto-the-bottom dynamics and the ensuing risk of forum shopping, ${ }^{9}$ or also to the prospect of expensive investment disputes that end up exerting pressure against strong State regulations, among other possibilities. It is also important to note that, in spite of their best efforts, as commented above, private transnational actors may elude or circumvent State controls through dissolution, relocation, or other strategies permitted by reliance on doctrines such as that of the corporate veil. ${ }^{10}$ In such events, States will be hard pressed to fulfill their functions of protecting their inhabitants, but may not be able to invoke binding international norms to advance their claims, for instance when it comes to request judicial or other cooperation from third States.

Against this backdrop, this article will explore how different actors in Latin America have dealt with problems related to business and human rights, and whether they have invoked the UNGPs, following this structure: in Part I, we will explore the notion of the UNGPs having become a vernacular that operates as a prism in light of which aspects related to business and human rights are now conceived and understood; also how such legal "language" can be appropriated and transformed by different actors in their practice. After this general and theoretical section, Part II will be devoted to the study of the trends and developments of the Inter-American Commission and Court of Human Rights in terms of the concepts presented in this Intro-

9 August Reinisch, The Changing International Legal Framework for Dealing with Non-State Actors, in Non-State Actors and Human Rights, 54-55 (Philip Alston, ed., Oxford University Press, Oxford, 2005).

10 Human Rights Council, Report on the first session of the open-ended intergovernmental working group on transnational corporations and other business enterprises with respect to human rights, with the mandate of elaborating an internationally legally binding instrument, $A / H R C / 31 / 50,5$ February 2016, paras. 50, 72, 88, 105. 
duction and Part I. Finally, Part III will study the most salient developments of the other participants in Latin America, namely businesses and States -e.g. in their National Action Plans, case law, norms, and decisions.

\section{THE GUIDING PRINCIPLES AS A VERNACULAR APPROPRIATED BY PARTICIPANTS THAT CAN HAVE SYNERGY WITH PROGRESSIVE DEVELOPMENT OR CONSERVATIVE APPROACHES}

Different stakeholders and actors in the Americas may resort to the Guiding Principles on Business and Human Rights strategically, framing their arguments in their light and, given the consensus supporting them, having a greater likelihood of their arguments being accepted and understood in the language and concepts they provide. The fact that the UNGPs are widely supported was acknowledged in the Americas by means of Resolution AG/RES.2840 (XLIV-0/14) of the General Assembly of the Organization of American States. Said resolution recognizes "the significant support expressed in the United Nations Human Rights Council for the Guiding Principles on Business and Human Rights: Implementing the United Nations "Protect, Respect, and Remedy" Framework, which includes the guidelines that enjoy the broadest with respect to protection and promotion of human rights in all spheres of business activity."

Alternatively, appropriation of the UNGPs may be the result of an unconscious internalization, in which the UNGPs become the de facto "vernacular" in which all discussions on business and human rights issues take place around the world, in and across the different regions. This section will explore how and why this may happen, and the three ways or dynamics in which the appropriation of the UNGPs and other developments may lead to new initiatives or to slowing others down. 


\section{A. The appropriation of the language of the UNGPs by regional actors}

For the reasons set forth in the Introduction of this article, in addition to internal norms, all that activists, Latin American States, and the human rights bodies of the Organization of American States have at their disposal, in terms of widely accepted and solid standards on the subject, are the Guiding Principles on Business and Human Rights.

In other words, the UNGPs and internal norms are all that the different participants in processes of interaction with international normative concepts and institutions have at their disposal in their interactions with and in the invocation of law in order to achieve policy goals ${ }^{11}$ related to the protection of human rights from corporate abuses.

Regarding the idea that different actors (participants) can interact with international normative concepts, it is useful to recall that Rosalyn Higgins has explained how:

[I]t is not particularly helpful, either intellectually or operationally, to rely on the subject-object dichotomy that runs through so much of the writings. It is more helpful, and closer to perceived reality, to return to the view of international law as a particular decision-making process. Within that process (which is a dynamic and not a static one) there are a variety of participants, making claims across state lines, with the object of maximizing various values. Determinations will be made on those claims by various authoritative decision-makers. ${ }^{12}$

Relevant participants also include academics as agents of political and legal change, "international lawyers as political actors," 13 and corporations themselves, since out of economic

11 Harold D. Lasswell and Myres S. McDougal, Jurisprudence in Policy-Oriented Perspective, XIX University of Florida Law Review (1966-67); Myres S. McDougal and Harold D. Lasswell, The Identification and Appraisal of Diverse Systems of Public Order, 53 The American Journal of International Law (1959).

12 Rosalyn Higgins, Problems \& Process: International Law and How We Use it, 50 (Oxford University Press, Oxford, 2004).

13 Arnulf Becker Lorca, Mestizo International Law, xii (Cambridge University Press, Cambridge, 2014). 
or political pressure, or an actual concern, the latter may internalize $^{14}$ the notions found in the UNGPs and other normative developments in their codes of conduct and practice.

The idea that regional stakeholders and participants in discussions related to business and human rights aspects encompass a multiplicity of actors is confirmed, for instance, by how States, intra-state bodies, civil society actors, international organizations, and others in the Americas, participated in a Regional consultation for Latin America and the Caribbean on public policy for the implementation of the UNGPs on Business and Human Rights in the Framework of the 2030 Agenda on Sustainable Development of the Working Group on the issue of human rights and transnational corporations and other business enterprises. $^{15}$

None of the above suggests that before the adoption of the UNGPs there were no trends, efforts, and developments towards the protection from the negative impact of businesses on the enjoyment of human rights. Quite the contrary, as explored below, such initiatives did exist, both universally and regionally. However, the widespread acceptance of the Guiding Principles does generate what could be termed a zeitgeist and an atmosphere in which corporate conduct is more scrutinized and placed under the spotlight in human rights terms. Moreover, they provide a common framework with which to assess pertinent issues.

Concerning these ideas, it is useful to consider that, as explained by Jan Klabbers, international law "offers a framework and a vocabulary for the conduct of politics." This is explained, from the point of view of constructivist and critical arguments, in the sense that "law provides a platform and a vernacular,

14 Harold Hongju Koh, Why Do Nations Obey International Law?, 106 The Yale Law Journal, 2601-2603, 2626-2627, 2634, 2641, 2646, 2649, 2651 (1997); Harold Hongju Koh, Internalization through Socialization, 54 Duke Law Journal, 981 (2005).

15 Human Rights Council, Report of the Working Group on the issue of human rights and transnational corporations and other business enterprises on the "Regional consultation for Latin America and the Caribbean on public policy for the implementation of the United Nations Guiding Principles on Business and Human Rights in the Framework of the 2030 Agenda on Sustainable Development," A/HRC/32/45/Add.4, 9 June 2016, paras. 13, 18-21. 
and [...] international law is inherently political." ${ }^{\text {"16 }}$ Insofar as law provides a common language in light of which reality can be understood and arguments advanced, it is no surprise that the different actors and participants with a vested interest - that can be bolstered or undermined by legal interpretations will try to frame their actions in legal terms, and those opposing them will likely try to challenge those assertions.

This has happened in other regimes, for instance in regards to conduct related to the use of force, as when the United States tried to convey a message that its intervention in Iraq was compatible with international law and others (rightly) challenged this idea. ${ }^{17}$ Discourse contestation also takes place when alleged abusers try to safeguard their "legal reputation,"18 and when those without enough resources try to frame adverse conduct as illegal, which is something the notion of "lawfare" -to us excessively focused on military issues partly refers to. ${ }^{19}$

Altogether, in order to achieve their aims, be it in the business and human rights or in other fields, different participants may resort to strategies not only resorting to the content of the standards, but also of "appropriating the international legal discourse" and legal thinking prevalent in influential circles (sometimes reinterpreting them). ${ }^{20}$ The aim is to frame their discourses in a language that is more appealing and seems to be the most robust at a given stage of international legal development, exchanging "opposing views articulated in a common language of international law," as explained by Arnulf Becker Lorca. ${ }^{21}$

\footnotetext{
16 Jan Klabbers, International Law, 13, 309 (Cambridge University Press, Cambridge, 2013).

17 Ibid., 308-309.

18 Antonio Remiro Brotóns et al., Derecho internacional, 50, 54-55 (Tirant Lo Blanch, Valencia, 2007).

19 Orde F. Kittrie, Lawfare: Law as a Weapon of War, 1-8 (Oxford University Press, Oxford, 2016).

20 Arnulf Becker Lorca, op. cit., 5, 73, 138, 140, 236, 303, 354.

21 Ibid., 4.
} 
B. The propelling or halting developments as a result of the internalization of the language of the Guiding Principles on Business and Human Rights

Why are the dynamics of appropriation of the "concepts" and "language" found in international standards relevant in relation to business and human rights issues? Because the different participants in the Americas and elsewhere will likely make arguments expressly invoking or relying on concepts and notions found in the UNGPs, as the most commonly accepted standards on the field, which would thus operate as a "shared language" or a "vernacular." By appropriating their use, they may -consciously or not subtly change the content of the concepts and standards of the Guiding Principles over time through practice. When there are economic or power imbalances, such as those present in some local contexts in which authorities or activists have tense relations with corporate or high-level authorities, actors in weak positions may be especially tempted to do so.

Altogether, by employing the language of the UNGPs, and framing their analyses in their light, actors may seek to strengthen their previous efforts with the support of a new widely accepted normative body, when they coincide -or are portrayed to coincide. In cases in which such coincidence does not exist, the adoption of the UNGPs in 2011 may inspire completely new actions. On the other hand, though, there is a risk of stagnation. If the scope of the UNGPs is restricted or limited in some regards, and such limitations are "internalized" by participants, otherwise potential developments of the latter may be forestalled.

Altogether, three dynamics of interaction with the Guiding Principles on Business and Human Rights may take place. The different participants in the Americas with a nominal/formal or actual interest on the protection from corporate abuses may invoke the Guiding Principles or-without necessarily expressly referring to them take advantage of the atmosphere generated by their adoption and their correlative expressive effects in order to: 
1. Reinforce preexisting -robust or incipient efforts (strengthening or crystallizing them, which are typical international legal processes): this happens when the language or concepts of the UNGPs are invoked in the conduction of strategies that existed before their adoption, e.g. if a Court criticized non-state abuses before, it can cite the UNGPs when such abuses are corporate ones, reinforcing its arguments; or

2. Generate new dynamics related to protection from the negative impact of businesses on human rights. In this case, thanks to the awareness generated by the UNGPs in relation to business and human rights problematics, authorities and defenders may be propelled to conduct processes and initiatives that they did not engage in before -e.g. litigating against corporations or sanctioning them if they did not do so before creating innovative programs to address and prevent the likelihood of corporate abuses.

3. On the other hand, whenever there is uncertainty about what the UNGPs or lex lata actually indicate, or when they fail to offer progressive and innovative venues of protection that are necessary de lege ferenda, there is a risk that:

4. Reliance on the UNGPs may hinder otherwise potential developments of protection -for instance, on issues of international legal responsibility (which the United States Supreme Court will probably examine in the future $)^{22}$ or concerning extraterritorial obligations, as the practice of the Inter-American Commission of Human Rights, explored in section II, reveals.

In the first two dynamics, the different participants may consciously or unconsciously appropriate the language of the UNGPs on aspects and notions as 'due diligence', among others, and may even end up transforming or making them evolve by

22 Julian Ku, The Unattractive Question is Back: SCOTUS (Again) Considers Corporate Liability Under the Alien Tort Statute, Opinio Juris (2017). http://opiniojuris.org/2017/04/03/unattractivequestion-back-scotus-considers-corporate-liability-alien-tort-statute/ 
means of their use and interpretation, when advancing certain policies and claims.

In fact, the dynamics described above can also take place when corporations or others try to deflect criticism by relying on a supposed "soft" or merely voluntary responsibility in some regards, with others challenging this position via the interpretation of existing standards, or by trying to bring about normative changes. Hence, it may happen that some arguments are framed in ways that allegedly rely on the concepts found in the UNGPs -and other standards that are eventually shared by consensus in ways that hinder or slow down stronger normative processes, for instance by saying that stronger alternative or complementary norms are unnecessary or could undermine the UNGPs.

That being said, discourse dynamics may also lead to progressive development, as has occurred throughout the history of international law. Furthermore, they can be instigated by or conducted prominently by semi-peripheral States-especially, as history shows, if they adopt a common stance or are joined by more influential actors such as powerful, especially interested, or affected States ${ }^{23}$ even from a formal point of view, in light of the notion of especially interested States in the formation of custom. ${ }^{24}$ Additionally, just as it happened with the notion of $u t i$ possidetis juris, which was initially an American doctrine that ended up being relevant in general international law, ${ }^{25}$ the efforts of American States, their reliance on and use of the UNGPs, and the climate they generate, may end up having an impact on ulterior universal legal developments.

In sum, the different participants of the Americas, by appropriating and perhaps eventually shaping -via customary law or otherwise both the notions and the scope and content of the duties found in the UNGPs (and other standards that eventually gain recognition as "common," shared, or widely accepted), can bring about normative change, at least in the region or sub-re-

23 Arnulf Becker Lorca, op. cit., 306, 332, 334, 349, 351.

24 North Sea Continental Shelf, Judgment, I.C.J. Reports 1969, 3, para. 73.

25 Frontier Dispute, Judgment, I.C.J. Reports 1986, 554, paras. 20-26. 
gions, going beyond what those standards expressly or avowedly say at a given moment. Those developments could eventually be echoed in other regions and in the universal level.

Yet, there is also the risk that the opposition of influential actors hinders the crystallization of those processes, as it can happen when such actors prove to be more persuasive in the invocation of the shared language of the norms on business and human rights in an opposing way. In any case, insofar as standards perceived to be common or "shared" generate the perception that they reflect the legal or normative reality, the success of processes of interaction will largely depend on effectively grasping and handling the concepts and terms found in them.

From the point of view of progressively developing and expanding the frontiers of what the law permits, activists and victims must bear in mind that "[d]eterminations will be made on those claims by various authoritative decision-makers." 26 Still, they may conduct initiatives in extra-legal venues and send messages to civil society seeking to bring about pressure on those authorities. To have success, emotional strategies are often important, especially if they manage to be expressed in discourses that employ the concepts of the UNGPs and to portray the drama of victims in public hearings or other settings. ${ }^{27}$

All of the previous dynamics can have a formal impact on international law, made possible because both invocation and implementation are international legal processes, as McDougal and Lasswell argued. ${ }^{28}$ Furthermore, practice can have an impact on future normative changes, as the relevance of the established practice of international organizations confirms. ${ }^{29}$ In this sense,

26 Rosalyn Higgins, op. cit., 50.

27 On the role of emotions in international law, see: Nicolás Carrillo Santarelli, La influencia "artística" de las emociones y la empatía en el contenido, la interpretación y la efectividad del derecho internacional, XVII Anuario Mexicano de Derecho Internacional (2017).

28 Harold D. Lasswell and Myres S. McDougal, Jurisprudence in Policy-Oriented Perspective, op. cit., 512-513; Myres S. McDougal and Harold D. Lasswell, The Identification and Appraisal of Diverse Systems of Public Order, op. cit., 9-10.

29 International Law Commission, Draft articles on the responsibility of international organizations, with commentaries, sixty-third session, 2011, paras. 17-18 of the Commentary to article 2; Antonio Remiro Brotóns et al., op. cit., at 262. 
it is possible to answer to the question of how change may be effected by employing the concepts of the UNGPs.

Firstly, this can take place thanks to the expressive effects ${ }^{30}$ of the UNGPs and other standards that come to be widely accepted, since they can generate new conscience and raise awareness on some problems that ought to be addressed, making actors perceive legal issues and reality in light of them (thus operating as a prism).

Secondly, actual practice, and a more or less faithful reliance on the UNGPs, may well generate new practices that go above and beyond what their author originally intended or the Principles themselves permit, require, or indicate. After all, expressive and implementation effects can sometimes exert a mutual influence, insofar as practice is shaped in light of existing standards, but the latter can be modified in turn by practice shaped by new expectations or dynamics, and so new expressive effects can be generated by this change.

We will now turn to the attention of how the main bodies of the Inter-American Human Rights System, namely the Commission and the Court, have treated business and human rights issues before and after the Guiding Principles were adopted, exploring how their practice fits in the conceptual framework presented in this section.

\section{DEVELOPMENTS AND RESPONSES CONCERNING BUSINESS AND HUMAN RIGHTS ISSUES BY THE INTER-AMERICAN COMMISSION AND COURT OF HUMAN RIGHTS}

The region of the Americas has witnessed accusations of serious abuses perpetrated or assisted by corporations, as the alleged cases of Chiquita Brands exemplify. ${ }^{31}$ The Inter-American $\mathrm{Hu}-$

30 Alex Geisinger and Michael Ashley Stein, A Theory of Expressive International Law, 60 Vanderbilt Law Review, 83, 86, 88-89, 94, 97, 130-131 (2000); Richard H. McAdams, The Expressive Powers of Law: Theories and Limits, 1-13 (Harvard University Press, Harvard, 2015).

31 See: Business \& Human Rights Resource Centre, Chiquita lawsuits (re Colombia). https:// 
man Rights System, embedded in the Organization of American States, has been led by its two main bodies, the Commission (hereinafter, IACHR) and the Court (hereinafter, IACtHR), which have had a case law that is deemed as progressive, and even as activist by some. ${ }^{32}$ Throughout their history, those bodies have conducted initiatives that have contributed to addressing serious human rights problems faced in the region, ranging from abuses of dictatorships, to violations of the rights of indigenous peoples, women, children, and migrants. ${ }^{33}$ Among them, the participation of businesses in violations has sometimes been raised before and tackled by both the IACHR and the IACtHR - both prior to and after the adoption of the UNGPs.

Such engagement with corporate participation in abuses has been facilitated by the fact that, from very early on, the Inter-American Human Rights System has considered that non-state actors, among which businesses are included, ${ }^{34}$ can violate human rights. This can be found in the decisions in the Velásquez-Rodríguez case and in more recent ones (e.g. in the Cotton Field case). ${ }^{35}$ It has been said that States precisely have

business-humanrights.org/en/chiquita-lawsuits-re-colombia.

32 Lucas Lixinski, Treaty Interpretation by the Inter-American Court of Human Rights: Expansionism at the Service of the Unity of International Law, 21 European Journal of International Law, 586, 590-591, 604 (2010).

33 Inter alia I/A Court H.R., Case of González et al. ("Cotton Field") v. Mexico. Preliminary Objection, Merits, Reparations and Costs. Judgment of November 16, 2009. Series C N. ${ }^{\circ} 205$; I/A Court H.R., Case of the "Street Children" (Villagrán-Morales et al.) v. Guatemala. Reparations and Costs. Judgment of May 26, 2001. Series C N. ${ }^{\circ}$ 77; I/A Court H.R., Juridical Condition and Rights of the Undocumented Migrants. Advisory Opinion OC-18/03 of September 17, 2003. Series A N.'18; I/A Court H.R., Juridical Condition and Human Rights of the Child. Advisory Opinion OC-17/02 of August 28, 2002. Series A N. ${ }^{\circ} 17$; I/A Court H.R., Rights and guarantees of children in the context of migration and/or in need of international protection. Advisory Opinion OC-21/14 of August 19, 2014. Series A N. ${ }^{\circ 21}$; I/A Court H.R., Case of the Mayagna (Sumo) Awas Tingni Community v. Nicaragua. Merits, Reparations and Costs. Judgment of August 31, 2001. Series C N. ${ }^{\circ} 79$.

34 United Nations Commission on Human Rights, Working paper on human rights and non-State actors submitted by Gáspár Biró and Antoanella-Iulia Motoc, E/CN.4/Sub.2/2005/40, 11 July 2005; Philip Alston, The "Not-a-Cat" Syndrome: Can the International Human Rights Regime Accommodate Non-State Actors?, in Non-State Actors and Human Rights (Philip Alston, ed., Oxford University Press, Oxford, 2005).

35 I/A Court H.R., Case of Velásquez Rodríguez v. Honduras. Merits. Judgment of July 29, 1988. Series C N. ${ }^{\circ}$ 4, paras. 166-172 (there may be "[a]n illegal act which violates human rights and which is initially not directly imputable to a State"); I/A Court H.R., Case of González et al. ("Cotton Field") v. Mexico. Preliminary Objection, Merits, Reparations and Costs. Judgment of November 16, 2009. Series C N. ${ }^{\circ} 205$, para. 252. 
some obligations to prevent and respond to non-state violations, as expressed under the theory of Drittwirkung. ${ }^{36}$

While some cases in which the IACHR and the IACtHR have explored aspects of business and human rights have indeed taken place even before the UNGPs were adopted in 2011 -as revealed by reports and decisions issued by the main bodies of the Inter-American System explored below it is possible to consider that there has been a renewed attention paid to the field of business and human rights afterwards. This may be explained by a variety of reasons.

As indicated in section I, the adoption of the Guiding Principles has generated expressive effects, signaling to different participants what the (construed) expectations on corporate conduct now are from a human rights point of view. This may have contributed to raising awareness and generating new expectations that have propelled human rights defenders, affected individuals and communities, and State agents, to demand more from corporations in terms of respect; and from authorities, in terms of protection and access to remedies -thus reflecting the three "protect, respect, and remedy" pillars of the Guiding Principles and the framework they are based upon. ${ }^{37}$ Given the new language and concepts of the UNGPs, participants may have been encouraged to discuss more business and human rights problems, which certainly existed before the UNGPs' adoption, in the System, thanks to the strengthened symbolic effects of the UNGPs and the increased stigma attached to corporate participation in abuses in an international landscape.

36 I/A Court H.R., Juridical Condition and Rights of the Undocumented Migrants. Advisory Opinion OC-18/03 of September 17, 2003. Series A N. ${ }^{\circ} 18$, paras. 140-153; I/A Court H.R., Juridical Condition and Human Rights of the Child. Advisory Opinion OC-17/02 of August 28, 2002. Series A N. ${ }^{\circ}$ 17, paras. 87-91; Concurring Opinion of Judge A.A. Cançado Trindade to: I/A Court H.R., Juridical Condition and Human Rights of the Child. Advisory Opinion OC-17/02 of August 28, 2002. Series A N. ${ }^{\circ}$ 17, paras. 63-64.

37 Human Rights Council, Protect, Respect, and Remedy: a Framework for Business and Human Rights. Report of the Special Representative of the Secretary-General on the issue of human rights and transnational corporations and other business enterprises, John Ruggie, $A / H R C / 8 / 5,7$ April 2008; United Nations, Guiding Principles on Business and Human Rights: Implementing the United Nations "Protect, Respect and Remedy" Framework, 2011, section 'General Principles', at 1; United Nations Working Group on Business and Human Rights, The UN Guiding Principles on Business and Human Rights: An Introduction, op. cit. 
We will now explore the most salient opinions of the IACHR and the IACtHR on the subject matter, both before and after 2011. This will allow us to identify a gradual increment in the intensity of how the System deals with business and human rights aspects, not only in reports when it is clear that there is no formal impediment to do so, but also in creative ways: in obiter dicta and even footnotes, by means of which the Court and Commission have expressed their non-contentious condemnation of corporate complicity and abuses; and by means of other innovative strategies, such as agreements of the IACHR and action plans.

It cannot be omitted that not every opinion or pronouncement on business and human rights aspects after 2011 has expressly referred to or mentioned the Guiding Principles. Yet, this does not detract from the idea that they have had an impact on the increased response of the system to the related problems since 2011, by raising awareness and reflecting a world consensus. Furthermore, it is important to consider that, by indirectly addressing corporate conduct, the Court may have an impact on domestic practice and standards via the notion of the "control of conformity with the Convention" (dubbed in Spanish control de convencionalidad), according to which, in the IACtHR's opinion, State authorities are bound to follow and implement its jurisprudence whenever this is pertinent, due to an alleged res interpretata function of the Court. ${ }^{38}$

\section{A. Engagement of the main bodies of the Inter-American Human Rights System with Business and Human Rights issues before the 2011 adoption of the Guiding Principles}

Among the cases in which business and human rights issues were handled by the Inter-American Human Rights System before the adoption of the UNGPs, it is possible to mention, for instance, Chapters VIII and IX of the 1997 country report of the

38 I/A Court H.R., Rights and guarantees of children in the context of migration and/or in need of international protection. Advisory Opinion OC-21/14 of August 19, 2014. Series A N. ${ }^{\circ}$ 21, para. 31. 
IACHR on the Situation of Human Rights in Ecuador, entitled "The Human Rights Situation of the Inhabitants of the Interior of Ecuador Affected by Development Activities" and "Human Rights Issues of Special Relevance to the Indigenous Inhabitants of the Country," respectively.

In those Chapters, the Commission acknowledged allegations of a lack of consultation and that certain corporate industrial and extractive activities had a detrimental impact on the environment and on local indigenous peoples -some of whom allegedly suffered harassment and threats of company workers or of men hired to intimidate them and of displacement at the hands of those who desired to conduct certain economic activities in their lands. In relation to these accusations, the Commission reminded the State of Ecuador that it had obligations to ensure that all victims had access to justice, no matter who the agent of causation of a negative impact on the enjoyment of human rights is -State, corporate, or otherwise and that indigenous peoples must receive special protection from corporate and other abuses. In this sense, in the aforementioned report, the IACHR said the following:

The inhabitants allege that the Government has failed to regulate and supervise the activities of both the state-owned oil company and of its licensee companies. They further allege that the companies take few if any measures to protect the affected population, and refuse to implement environmental controls or to utilize existing technologies employed in other countries [...] Human exposure to oil and oil-related chemicals, through the skin or ingested in food or water, or through fumes absorbed via the respiratory system, has been widely documented to cause adverse effects to human health and life [...] Oil development activities have also been linked, directly and indirectly, with problems in food supply and malnutrition [...] The information analyzed above on the impact of oil exploitation activities on the health and lives of the affected residents raises serious concern, and prompts the Commission to encourage the State of Ecuador to take the measures necessary to ensure that the acts of its agents, through the State-owned oil company, conform to its domestic and inter-American legal obligations. Moreover, the Commission encourages the State to take steps to prevent harm to affected individuals through the conduct of its licensees and private actors. The State of 
Ecuador must ensure that measures are in place to prevent and protect against the occurrence of environmental contamination which threatens the lives of the inhabitants of development sectors. Where the right to life of Oriente residents has been infringed upon by environmental contamination, the Government is obliged to respond with appropriate measures of investigation and redress [...] The Commission recommends that the State implement the measures to ensure that all persons have the right to participate, individually and jointly, in the formulation of decisions which directly concern their environment [...] the Commission recommends that the State take measures to ensure that access to justice is more fully afforded to the people of the interior [...] In addition to the non-native workers brought in to build roads and construct and operate facilities, the opening of roads funneled colonists, land speculators, and loggers into indigenous homelands. In the case of the Oriente, this colonization was encouraged by the State [...] One consequence of the influx of non-native peoples into traditional indigenous territory is the exposure of indigenous inhabitants to previously unknown diseases and epidemics [...] Another consequence of the development of the Oriente and the influx of outsiders has been the displacement of indigenous inhabitants and communities. Oil exploitation activities have proceeded through traditional indigenous territory with little attention to the placement of facilities in relation to existing communities [...] Reports indicate that the Tagaeri have been threatened by company workers or bands of armed men hired to seek them out to harm or intimidate them, and by adventurers. The Commission delegation received detailed accounts of several such incidents [...] Within international law generally, and inter-American law specifically, special protections for indigenous peoples may be required for them to exercise their rights fully and equally. ${ }^{39}$

On the other hand, it is also important to mention that the IACHR adopted its report on Indigenous and Tribal Peoples' Rights over Their Ancestral Lands and Natural Resources in December 2009, more than one year after the Human Rights Council unanimously approved Ruggie's "Protect, Respect, and Remedy: a Framework for Business and Human Rights" proposal in April 2008. ${ }^{40}$ Notwithstanding the importance of the

39 Inter-American Commission on Human Rights, Report on the Situation of Human Rights in Ecuador, OEA/Ser.L/V/II.96, Doc. 10 rev. 1, 24 April 1997, Chapters VIII and IX.

40 Human Rights Council, Protect, Respect, and Remedy: a Framework for Business and Human Rights. Report of the Special Representative of the Secretary-General on the issue of human rights and transnational corporations and other business enterprises, John Ruggie, $A / H R C / 8 / 5$, 7 April 2008. 
Framework, upon which the UNGPs themselves are founded, it may be the case that the Guiding Principles on Business and Human Rights are far more recognized and hailed as the current expression of the consensual state of the art on the issue, being the ones that are frequently mentioned as important to not be disregarded or undermined but rather complemented by a future treaty or practice. ${ }^{41}$ Yet, the report was undoubtedly adopted at a moment in which some of the notions they discuss had begun to gain prominence, given the adoption of the Framework. The Report of the Commission is noteworthy for the purposes of our study to the extent that it confirmed the previously identified jurisprudential line of the Commission according to which States are under an obligation to protect indigenous peoples from the negative impact on the enjoyment of the rights of their members caused by corporate activity that generates environmental degradation or is aimed at threatening and harassing them. It also indicated that, when such prevention fails, States are under a duty to provide access to justice and ensure reparations. In this sense, the IACHR considered that:

[E]nforcement of the environmental protection measures in relation to private parties, in particular of extractive companies and industries, is required to avoid the State's international responsibility [...] extractive concessions in indigenous territories, in having the potential of causing ecological damage, endanger the economic interests, survival, and cultural integrity of the indigenous communities [...] In too many cases, the consultation of indigenous peoples is carried out in climates of harassment and even violence perpetrated by private security guards hired by the companies that are responsible for the projects, and sometimes by public security forces [...] the duty of reparation is applicable not only to the negative impact of activities carried out by State authorities, but also by commercial companies or other private actors. In this latter type of cases, states are in the obligation of securing the existence of effective and accessible reparation mechanisms. ${ }^{42}$

41 Human Rights Council, Report on the first session of the open-ended intergovernmental working group on transnational corporations and other business enterprises with respect to human rights, with the mandate of elaborating an internationally legally binding instrument, $A / H R C / 31 / 50,5$ February 2016, paras. 3, 23, 29, 39, 79.

42 Inter-American Commission on Human Rights, Indigenous and Tribal Peoples' Rights over 
In addition to country and thematic reports, the Inter-American Commission on Human Rights also addressed the risks that some corporate conduct poses to the enjoyment of human rights in Resolution N. ${ }^{\circ}$ 12/85 in the Yanomami case. In this Resolution, the IACHR noted how the discovery of mineral deposits in the 1970s "attracted mining companies and independent prospectors (garimpeiros), thus aggravating the displacement of thousands of Indians," and that in addition to such displacement, the "massive penetration of outsiders into the area has had devastating physical and psychological consequences for the Indians." Accordingly, and considering that the State of Brazil had forbidden the transit or stay of non-indigenous individuals and the entrance of companies into the Yanomami territories, the Commission urged the State to continue implementing preventive measures of the sort. ${ }^{43}$

In turn, the Inter-American Court of Human Rights had also addressed corporate participation in abuses or threats before the adoption of the Guiding Principles on Business and Human Rights. In this sense, in its Provisional Measures Resolution dated March 6 $6^{\text {th }}, 2003$ in the Case of the Communities of the Jiguamiandó and the Curbaradó, the Court considered how "the company Urapalma S.A. has initiated cultivation of the oil palm on approximately 1,500 hectares of the collective land" of some communities, which suffered raids from armed groups with the aim of intimidating them into joining "in the production of oil palm or evacuate the territory." Moreover, the company was expanding cultivations in a way that made crops "advance toward the community of Nueva Esperanza, near the place chosen by the members of the Communities to set up their "humanitarian refugee zones." Accordingly, the IACtHR identified a risk to the enjoyment of human rights suffered by the members of the respective communities, and partly caused by corporate activity,

their Ancestral Lands and Natural Resources: Norms and Jurisprudence of the Inter-American Human Rights System, OEA/Ser.L/V/II, Doc. 56/09, 30 December 2009, paras. 203, 206, 318, 385.

43 Inter-American Commission on Human Rights, Resolution N. ${ }^{\circ}$ 12/85, Case N. . 7615, Brazil, 5 March 1985. 
in the sense that "under [the] circumstances, the cultivation of African palm and the exploitation of the natural resources on the Communities' territory endanger the lives and survival of these families." 44

As a consequence of its findings, the Court called upon the State of Colombia to protect those members through measures as the conduction of investigations and actions aimed at safeguarding their life and safety and their right to "continue living in their place of residence, free from any kind of coercion or threat." 45

This is one of the orders of the Court that, on the one hand, have been praised for its technique of requiring, via Provisional Measures, the protection of everyone who is an identifiable victim or potential victim, ${ }^{46}$ and on the other hand, demonstrates that protection can be demanded when individuals and communities are threatened by the activity of corporations. Furthermore, this case exemplifies the seriousness of the risks and abuses that have been faced by some people in the region at the hands of certain businesses.

Let us now move on to the analysis of the most relevant pronouncements and initiatives in the Inter-American System that were issued after the adoption UNGPs, which reveal an increase in the energy devoted and the attention paid to business and human rights issues.

44 I/A Court H.R., Matter of The Communities of Jiguamiandó and Curvaradó regarding Colombia. Provisional Measures. Order of the Inter-American Court of Human Rights of March 06, 2003.

45 Ibid.

46 Concurring Opinion of Judge A.A. Cançado Trindade to: I/A Court H.R., Matter of The Communities of Jiguamiandó and Curvaradó regarding Colombia. Provisional Measures. Order of the Inter-American Court of Human Rights of March 06, 2003, para. 2; Jo M. Pasqualucci, The Practice and Procedure of the Inter-American Court of Human Rights, 263 (2nd ed., Cambridge University Press, Cambridge, 2013). 
B. Examination of corporate participation in abuses in the Inter-American Human Rights System since the adoption of the Guiding Principles on Business and Human Rights in 2011

Beginning with the Inter-American Court of Human Rights, it is noteworthy how, thanks to the universal normative developments explored in this article, when it has examined recent cases in which elements of corporate participation in abuses are present, the Court has done two things: first, it has relied on the Drittwirkung or horizontal human rights law doctrine as it did before, but specifically mentioning the global developments towards protection from corporate violations in ways that make it clear that the Court rejects and condemns such abuses; and secondly, while the IACtHR cannot condemn corporate abuses in a strictly judicial way in the conduction of contentious procedures, given its jurisdictional limits, in obiter dicta it has expressed its repudiation and thus sent signals - not only to authorities, but also to businesses themselves, and to victims and their defenders that corporate abuses are unacceptable, just as it has done in regards to acts of terrorism. ${ }^{47}$ Two cases reveal this.

Firstly, it would be remiss to fail to mention the landmark judgment of the IACtHR in the case of the Kaliña and Lokono Peoples, which is noteworthy insofar as it prominently mentions the Guiding Principles on Business and Human Rights, and also underscores the unacceptability of the corporate conduct it had to examine in order to assess State compliance with human rights obligations. In the part of its decision that is relevant for the purposes of this article, the Court began by acknowledging that some corporate conduct had a negative impact on human rights, and how this was contrary to what the Guiding Principles indicate concerning the respect that businesses should have to-

47 I/A Court H.R., Case of Castillo Petruzzi et al. v. Peru. Merits, Reparations, and Costs. Judgment of May 30, 1999. Series C N. ${ }^{\circ}$ 52, para. 89; I/A Court H.R., Case of the Miguel Castro Castro Prison v. Peru. Interpretation of the Judgment on Merits, Reparations and Costs. Judgment of August 2, 2008 Series C N. ${ }^{\circ} 181$, paras. 40-43. 
wards human rights. Said is the reason why the protection pillar ought to be activated and the responded State, Suriname, was under protection obligations of both prevention and response, which it failed to observe. The relevant extracts of the 2015 judgment say the following:

223. The Court notes that the mining activities that resulted in the adverse impact on the environment and, consequently, on the rights of the indigenous peoples, were carried out by private agents; first by Suralco alone, and then by the joint venture, BHP Billiton-Suralco.

224. In this regard, the Court takes note of the "Guiding Principles on Business and Human Rights," endorsed by the Human Rights Council of the United Nations, which establish that businesses must respect and protect human rights, as well as prevent, mitigate, and accept responsibility for the adverse human rights impacts directly linked to their activities. Hence, as reiterated by these principles, "States must protect against human rights abuse within their territory andlor jurisdiction by third parties, including business enterprises. This requires taking appropriate steps to prevent, investigate, punish, and redress such abuse through effective policies, legislation, regulations, and adjudication."

225. Thus, the Special Representative of the Secretary-General of the United Nations on the issue of human rights and transnational corporations and other business enterprises has indicated that businesses must respect the human rights of members of specific groups or populations, including indigenous and tribal peoples, and pay special attention when such rights are violated.

226. Based on the above, the Court finds that, because the State did not ensure that an independent social and environmental impact assessment was made prior to the start-up of bauxite mining, and did not supervise the assessment that was made subsequently, it failed to comply with this safeguard; in particular, considering that the activities would be carried out in a protected nature reserve and within the traditional territories of several peoples. ${ }^{48}$ (original underscored).

Likewise, in the case of the Hacienda Brasil Verde Workers, the Court recounted violations of slave work in estates belonging to businesses in Brazil in the 20th century and actions that the State had taken to address this problematic. It highlighted that

48 I/A Court H.R., Case of the Kaliña and Lokono Peoples v. Suriname. Merits, Reparations, and Costs. Judgment of November 25, 2015. Series C N. ${ }^{\circ} 309$, paras. 223-226. 
States are under obligations to bring an end to slavery through measures as addressing its causes, and concluded that Brazil, the respondent State, had breached its obligations -it did cite the Guiding Principles, albeit in a footnote. ${ }^{49}$

As to the Inter-American Commission on Human Rights, it is convenient to begin by noting that while, just as the Court, it is currently prevented from having the capacity to issue direct conclusions on non-state conduct in the exercise of its contentious jurisdiction; it can both address non-state abuses indirectly by means of obiter dicta in the exercise of such jurisdiction and, additionally, it can give opinions on corporate and other non-state threats to the enjoyment of human rights in press releases and thematic and country reports, in furtherance of its promotion function and mission. While, understandably, it still focuses on State responsibility, the Commission ever more addresses nonstate abuses, which, needless to say, is an important action for victims and is consistent with the idea that human dignity, being non-conditional, must be protected from all threats, corporate ones included. ${ }^{50}$ In regards to its functions and capacities, in its Report on Terrorism and Human Rights the IACHR argued that it would be false to consider that:

[T] he conduct of non-state actors, including terrorists and terrorist groups, bears no relevance to the evaluation of states' obligations concerning human rights protections in the Hemisphere. Throughout its history, the Commission has, for example, referenced the atrocities committed by armed dissident groups in its press releases, in communications with governments, and in its reports on the situation of human rights in the various member states of the OAS. ${ }^{51}$

Having presented the basics of the competence of the IACHR on the issue, we will now present the most salient reports of the

49 I/A Court H.R., Case of the Hacienda Brasil Verde Workers v. Brazil. Preliminary Objections, Merits, Reparations, and Costs. Judgment of October 20, 2016. Series C N. 318 , paras. 111, 183,318 , footnote 452 therein.

50 Nicolás Carrillo-Santarelli, Inconvenient and Unnecessary? A Defense of Direct International Human Rights Obligations of (All) Corporations, op. cit.

51 Inter-American Commission on Human Rights, Report on Terrorism and Human Rights, $O E A$ / Ser.L/V/II.116, Doc. 5 rev. 1 corr., 22 October 2002, para. 48. 
Commission on business and human rights aspects, beginning with its report on Indigenous Peoples, Communities of African Descent, Extractive Industries. In it, the Commission not only expressly referred to the Guiding Principles and acknowledged that corporate conduct-investment activities included can have a negative impact on human rights (generally speaking, and in the case of vulnerable persons, such as children or Afro-descendants; and also in relation to rights with an environmental connection), reason why they are required to be compatible with said rights (which is a systemic argument that helps to counter fragmentation), ${ }^{52}$ but also noted thorny and still debated topics such as extraterritorial jurisdiction, argued that impact assessments are important, and that barriers to remedies and redress mechanisms are a problem to be addressed, since they generate impunity. Relevant parts of the report say the following:

[W] hen [...] complaints are brought to the justice system, the petitioners must go through a series of obstacles and barriers that create situations of impunity [...] Where investment projects involve foreign or transnational corporations originating from outside of the host country, situations of impunity are exacerbated [...] indigenous representatives and human rights defenders from various countries of the region have been unanimous in reporting and documenting the deficiencies in the current legal and political frameworks and emphasizing the need for foreign and transnational corporations to also be held accountable in their home countries for actions that violate the human rights of indigenous peoples and Afro-descendants in the Americas [...] States must not adopt commercial or investment legislation that can weaken, undermine, or deny the existing protections and their international human rights obligations $[\ldots .$.$] The Commission reiterates its concern that while business and invest-$ ment is a laudable objective to be encouraged, it must be carried out on a platform that enhances and does not undermine human rights, within or beyond national borders [...] the adoption of measures to ensure the investigation and, where appropriate, the application of criminal and administrative sanctions to the people in the public or private sphere, and companies responsible for human rights violations is required..$^{53}$

52 International Law Commission, Conclusions of the work of the Study Group on the Fragmentation of International Law: Difficulties arising from the Diversification and Expansion of International Law, Fifty-eighth session (2006), paras. 1, 17-19.

53 Inter-American Commission on Human Rights, Indigenous Peoples, Communities of African 
The previous ideas of the IACHR indeed support the strengthening of protection from corporate abuses, and show how reliance on the language of the UNGPs and other developments may strengthen the case for protection from corporate abuses and the position of defenders, as argued in section I. Yet, the limits that the Principles themselves have in some regards -which do not necessarily reflect the final stage of the evolution of the law or even the contemporary one ${ }^{54}$ may also hinder or slow down potential developments when they are fully or blindly embraced, as section I also discussed, making the importance of further developments, including those that can potentially take place in the region, so important.

This risk can be seen in the treatment of extraterritorial jurisdiction, insofar as the Guiding Principles cited by the very Commission mention, in the commentary to Principle 2, that "[a]t present States are not generally required under international human rights law to regulate the extraterritorial activities of businesses domiciled in their territory and/or jurisdiction. Nor are they generally prohibited from doing so, provided there is a recognized jurisdictional basis."

Recognizing the problems generated by the availability of different jurisdictions for corporate activities and how businesses can circumvent internal controls of some States, the IACHR goes on to note that there are certainly protection gaps, and thus urges (does not demand) States to adopt extraterritorial jurisdiction, stopping short of requiring this as a matter of legal obligations. In this sense, the Commission considered in its report that:

[T] he IACHR, taking note of evolving principles in international law and the work of other human rights monitoring bodies, has set out

Descent, Extractive Industries, OEA/Ser.L/V/II, Doc. 47/15, 31 December 2015, paras. 19-20, 52, 53, 74, 77-81, 100, 131, 138-139, 144, 328.

54 Human Rights Council, Report on the first session of the open-ended intergovernmental working group on transnational corporations and other business enterprises with respect to human rights, with the mandate of elaborating an internationally legally binding instrument, $A / H R C / 31 / 50,5$ February 2016, paras. 23, 79; XXVI Ordinary Session of the Human Rights Council, Statement of Archbishop Silvano M. Tomasi, Permanent Observer of the Holy See to the United Nations and Specialized Agencies in Geneva, 11 June 2014. http://www.vatican.va/roman_curia/secretariat_state/2014/documents/rc-seg-st-20140611_tomasi-diritti-umani_en.html 
certain fundamental principles concerning the use of extraterritorial jurisdiction. It is therefore jurisprudentially sound to understand that a State may be accountable under international human rights law for conduct that takes place in another country when the first state's acts [...] While this is an emerging and evolving area, now the subject of deep discussion at the United Nations level, some definitive statements have already been expressed by certain UN bodies about the duty of states to protect human rights, specifically to prevent human rights violations, even in relation to alleged violations by its nationals in other countries. The IACHR continues to urge foreign states of origin to put mechanisms in place voluntarily [...] The Commission had in fact noted in hearings that these rules do not establish specific monitoring mechanisms that could be used in corporation operations abroad..$^{55}$

In any case, while adopting a cautious or conservative stance not shown by United Nations treaty-supervisory bodies, ${ }^{56}$ probably influenced by what the Guiding Principles indicate, the Inter-American Commission's argument has the redeeming quality that it does not foreclose the possibility of there being an evolution in the regulation of extraterritorial jurisdiction -the evolutionary nature of how human rights law is defended supports this position ${ }^{57}$ generally and in connection with business and human rights issues. In fact, this possibility, and the necessity of there being normative evolutions in the field, exist so much so

55 Ibid., paras. 79-80.

56 Committee on Economic, Social, and Cultural Rights, General Comment on State Obligations under the International Covenant on Economic, Social, and Cultural Rights in the Context of Business Activities: Draft prepared by Olivier De Schutter and Zdzislaw Kedzia, Rapporteurs, E/C.12/60/R.1, 17 October 2016, paras. 30-40; Committee on Economic, Social, and Cultural Rights, General comment N. 23 (2016) on the right to just and favorable conditions of work (article 7 of the International Covenant on Economic, Social, and Cultural Rights), E/C.12/ GC/23, 27 April 2016, paras. 69-70; Committee on the Elimination of Discrimination against Women, General recommendation N. ${ }^{\circ} 34$ (2016) on the rights of rural women, $C E D A W / C /$ GC/34, 7 March 2016, para. 13.

57 I/A Court H.R., Entitlement of legal entities to hold rights under the inter-American human rights system (Interpretation and scope of Article 1(2), in relation to Articles 1(2), 8, 11(2), 13, $16,21,24,25,29,30,44,46$ and 62(3) of the American Convention on Human Rights, as well as of Article 8(1)(A) and (B) of the Protocol of San Salvador). Advisory Opinion OC-22/16 of February 26, 2016. Series A N. ${ }^{\circ} 22$, paras. 49-50, 63; I/A Court H.R., Rights and guarantees of children in the context of migration and/or in need of international protection. Advisory Opinion $O C-21 / 14$ of August 19, 2014. Series A N..$^{\circ} 21$, paras. 55, 57, 59; I/A Court H.R., Interpretation of the American Declaration of the Rights and Duties of Man within the Framework of Article 64 of the American Convention on Human Rights. Advisory Opinion OC-10/89 of July 14, 1989. Series A N. ${ }^{\circ} 10$, paras. 37-38. 
that the United States Court of Appeals for the Second Circuit, which considered in the Kiobel case that there are no contemporary direct obligations of businesses under international law (something that authors such as ourselves and other U.S. Courts and even Arbitral Tribunals disagree with), ${ }^{58}$ accepted that this situation can change to the extent that obligations of that kind may be created and regulated in the future, when it said "[w] e do not know whether the concept of corporate liability will "gradually ripen[ ] into a rule of international law." 59

In addition to the previous report on extractive industries, in which business and human rights analyses and reference to the UNGPs abound, ever since 2011, the IACHR has engaged the issue in a more frequent and proactive way, perhaps spurred by the adoption of the UNGPs as catalysts of innovation and action. For instance, in 2015 the Commission adopted a country report on Guatemala, in which, sticking to its main focus on State obligations and how they remain in place even when companies carry out certain operations, it confirmed that businesses regrettably do violate human rights in practice, and expressed its concern over some possible chilling effects affecting litigation against them; possible threats of private security companies, among others; and how economic reasons may motivate or be behind some abuses. Concerning these issues, in the aforementioned report the IACHR said the following:

An especially critical issue in the field of security is the operation of private security forces in Guatemala [...] The IACHR also notes that members of private security forces have been accused repeatedly of violating the rights of indigenous communities and their members defending their land and territory [...] the State's international responsibility may be engaged by the attribution to it of human rights violations committed by third parties or private individuals [...] numerous acts of violence

58 International Centre for Settlement of Investment Disputes, Urbaser S.A. and Consorcio de Aguas Bilbao Bizkaia, Bilbao Biskaia Ur Partzuergoa Vs. The Argentine Republic, ICSID Case N. ARB/07/26, Award, 8 December 2016, paras. 1193-1200; United States Court of Appeals, Seventh Circuit, Boimah Flomo, et al., Plaintiffs-Appellants, v. Firestone Natural Rubber Co., LLC, Defendant-Appellee, N. ${ }^{\circ}$ 10-3675, 11 July 2011.

59 United States Court of Appeals for the Second Circuit, Docket Nos. 06-4800-cv, 06-4876-cv, 17 September 2010, at 49. 
have been observed against indigenous communities that oppose development and investment projects, in particular, attacks, intimidation, and harassment against their leaders [...] Opening groundless criminal investigations or judicial actions against human rights defenders not only has a chilling effect on their work. ${ }^{60}$

Indeed, the problems posed by certain security companies are worrisome in the region and have been raised in other reports as well, such as in the 2015 report on Mexico, in which the IACHR said that "private security forces also tend to be sources of violence. Should these private companies commit human rights violations, the State could be responsible." ${ }^{61}$ Likewise, in its 2015 report on Honduras, the Commission put forth that private security companies "have acquired power and are working without proper supervision and control, and hence with impunity." ${ }_{2}$ Indeed, the problems that the aforementioned companies can pose require special State oversight. In this regard, in its 2015 report on Violence, Children and Organized Crime, the IACHR said that:

The IACHR has also voiced its concern over poor regulation and oversight by the State in several countries, particularly, with regard to: i) the functions that private security companies are allowed to perform; ii) the type of weapons and law enforcement equipment they are authorized to use; iii) adequate mechanisms to control their activities; iv) implementation of a public register of such companies and employees; and v) delivery of regular reports on contracts entered into and the type of activities performed by them. ${ }^{63}$

Additionally, the Inter-American Commission on Human Rights has addressed other specific business and human rights problems in the Americas, as it did in its 2016 report on the

60 Inter-American Commission on Human Rights, Situation of Human Rights in Guatemala, OEA/Ser.L/V/II. Doc. 43/15, 31 December 2015, paras. 136, 138-139, 196, 218.

61 Inter-American Commission on Human Rights, The Human Rights Situation in Mexico, OEA/ Ser.L/V/II, Doc. 44/15, 31 December 2015, para. 51.

62 Inter-American Commission on Human Rights, Situation of Human Rights in Honduras, OEA/ Ser.L/V/II, Doc. 42/15, 31 December 2015, para. 40

63 Inter-American Commission on Human Rights, Violence, Children, and Organized Crime, OEA/Ser.L/V/II, Doc. 40/15, 11 November 2015, para. 85. 
Criminalization of Human Rights Defenders. In this report it said that sometimes the owners of business megaprojects, those who work in them, or private companies themselves, "file complaints within unfounded criminal prosecutions," and "sometimes conduct smear campaigns against human rights defenders in order to affect their credibility, and materialize alliances with military and police officers to obtain the arrests of human rights defenders." ${ }^{64}$ Likewise, in its 2015 report on Human Mobility, Inter-American Standards, the Commission said that "the impact of the activity of national and transnational business" may be a factor contributing to an increase in human mobility in the region, ${ }^{65}$ which sometimes takes place in ways that generate or are surrounded by human rights problems.

In addition to its ordinary functions, it is noteworthy that the Inter-American Commission on Human Rights entered into a Memorandum of Understanding with the Danish Institute for Human Rights on 16 March 2015, in which both parties agreed, among others, to enhance cooperation "in the areas of promotion and protection of economic, social, and cultural rights [...] with particular focus on the areas of business and human rights and sustainable development in the Americas. All work will be based on applicable international and regional human rights principles and instruments, including the UNGPs" (original underscored). According to the Danish Institute, the agreement:

[C]omes on the heels of the adoption of a OAS General Assembly resolution from June 2014 concerning the promotion and protection of human rights in business, in which the General Assembly resolved to promote the application of the UNGPs and encourages member states and their national human rights institutions to foster constructive dialogue among all stakeholder groups on the application of the UNGPs. The resolution also requests the IACHR to support states in the promotion and appli-

64 Inter-American Commission on Human Rights, Criminalization of Human Rights Defenders, OEA/Ser.L/V/II, Doc. 49/15, 31 December 2015, para. 68.

65 Inter-American Commission on Human Rights, Human Mobility, Inter-American Standards, OEA/Ser.L/V/II, Doc. 46/15, 31 December 2015, para. 17. 
cation of state and business commitments in the area of human rights and business. ${ }^{66}$

In addition to implicitly reflecting how actors as varied as an Institute and the IACHR itself and its Rapporteurship on Economic, Social, and Cultural Rights (entrusted with the object of the agreement) are concerned with the impact of business activities on the enjoyment of those and other human rights (as the reports addressing private security violence reveal), the Memorandum of Understanding underscores how joint and individual action addressing corporate impact on the enjoyment of human rights can be carried out with reference to the Guiding Principles on Business and Human Rights, which have been erected as the de facto corpus juris on the field (undoubtedly codifying some preexisting standards) ${ }^{67}$ More than that, it shows how the UNGPs have propelled new initiatives and made different actors pay attention to a problem that, perhaps, was not so evident before or concerning which some (out of a given interest) wanted to turn a deaf ear to.

Initiatives as those studied herein by no means suggest that corporate human rights problems are new, because by no means they are. Rather, the agreement and other actions in the Inter-American System evince how the UNGPs have raised awareness about them and operate as a shared body of reference that permits interactions and discussions about it. Yet, there is also the risk, identified in doctrine, that exclusively referring to those Guiding Principles could lead to stagnation when there are pressing problems not sufficiently addressed by them, ${ }^{68}$ as

66 The Danish Institute for Human Rights, Collaboration on human rights and business starts with the Americas. https://www.humanrights.dk/news/collaboration-human-rights-businessstarts-americas

67 United Nations Working Group on Business and Human Rights, The UN Guiding Principles on Business and Human Rights: An Introduction, op. cit.; United Nations Office of the High Commissioner for Human Rights, Introductory training on to the Guiding Principles on Business and Human Rights, Second Annual Forum on Business and Human Rights, 2 December 2013. http://www.ohchr.org/Documents/Issues/Business/ForumSession2/guidingprinciples_en.pdf

68 Surya Deva, op. cit. 
argued above when referring to extraterritorial jurisdiction in the IACHR's analysis.

Altogether, the information provided in this section on the reports and initiatives of the Inter-American Commission reveal that, while it does not always expressly refer to the Guiding Principles on Business and Human Rights, it does seem both more aware of the importance of recognizing how some corporate conduct may cause or worsen some human rights problems, and also more willing to tackle such conduct -directly or indirectly. The fact that its thematic and country reports increasingly address such ratione personae dimension since the adoption of the UNGPs suggests that they may have had raised awareness and propelled new and renewed efforts to address it, especially because IACHR reports did not always or so frequently consider corporate impact before.

On the other hand, in their actions, both the IACHR and the IACtHR had historically taken into account non-state abuses and how they may trigger or intensify State obligations. Thus, the appropriation of the UNGPs as a shared corpus has served to reinforce initiatives to protect from corporate abuses, by providing accepted international standards and the reflection of a supposed common conscience -which has an impact on perception and beliefs of actors and participants.

Moreover, the opinions of both the Court and the Commission echo the three 'protect, respect, and remedy' pillars of the UNGPs and their Framework, to the extent that they acknowledge that businesses may be agents of human rights violations, that States are obliged to protect from that possibility, and that victims must have access to remedies and justice in those and all other cases of violations.

What is more, the shared corpus represented by the UNGPs may operate in synergic relations. In this sense, first, States may be influenced to incorporate them in their practice and norms, not only due to requests at the United Nations but also via the figure of the "control of conformity with the Convention", as indicated earlier in this section; or simply by internalizing what 
the Inter-American System says, not only out of a sense of duty, but even as a result of imitation, acculturation, or socialization dynamics. ${ }^{69}$ Other actors can follow suit by internalizing the UNGPs and related standards in other ways. For instance, the shared language has been adopted by other actors within the OAS.

In this sense, for example, Resolution AG/RES.2840 (XLIV0/14) of the General Assembly of the Organization of American States, recognizing the broad international support of the UNGPs, promoted its reception in member States, and asked for discussions on business and human rights issues to be made in their light. In this sense, the Resolution resolved:

To continue promoting the application of the United Nations guiding principles on business and human rights, and to urge member states to disseminate these principles as broadly as possible, facilitating the exchange of information and sharing of best practices on promotion and protection of human rights in business in order to create greater awareness of the benefits of their enforcement [...] To encourage member states and their respective national human rights institutes and/or competent institutions to foster constructive dialogue among business, government, and civil society and other social stakeholders, for application of the Guiding Principles.

The idea that the Guiding Principles on Business and Human Rights serve as an important part of the common "language" or framework with which to address the impact of corporate activity on human rights in the Americas has also been expressed in Inter-American conferences and OAS meetings. Indeed, it has been said that:

"[A]t the Inter-American level, countries have not developed a regional standard, guideline or directive on corporate social responsibility, but have

69 Ryan Goodman and Derek Jinks, Incomplete Internalization and Compliance with Human Rights Law, 19 European Journal of International Law (2008); David Capie, Influencing Armed Groups: Are there Lessons to Be Drawn from Socialization Literature?, in Exploring Criteria \& Conditions for Engaging Armed Non-State Actors to Respect Humanitarian Law \& Human Rights Law, Conference Report, Geneva, 4-5 June 2007 (Geneva Call, Geneva, 2008); Harold Hongju Koh, Why Do Nations Obey International Law?, op. cit. Harold Hongju Koh, Internalization through Socialization, op. cit. 
rather accepted as valid or applicable in the relevant countries - of course, with a voluntary nature the universal documents prepared by different organizations, such as the 2000 United Nations Global Compact, the 2006 ILO Tripartite Declaration of Principles concerning Multinational Enterprises and Social Policy, the 2010 ISO 26000, the 2011 Guidelines for Multinational Enterprises of the Organisation for Economic Co-operation and Development (OECD) and the 2011 Guiding Principles on Business and Human Rights: Implementing the United Nations 'Protect, Respect and Remedy' Framework (Ruggie Principles)" ${ }^{\text {"70 }}$ (original underscored).

The previous considerations confirm that the UNGPs operate as a prominent part of a corpus juris on the subject matter under examination in the Americas. But that is only part of the story: through their appropriation as a de facto standard that is relevant in the region and has a universal origin, specifics on its implementation may vary or evolve through constant practice in the regional level, and eventually such practice may influence or inspire similar or alternative trends elsewhere, regionally or universally. In addition to proper regional bodies, the respective practice and implementation may also take place locally in societies within the region, with State and other actors participating in it, sometimes having an impact on regional and universal custom via their own developments - perhaps even influencing what the Inter-American Human Rights System says later in accordance with what dialogue and normative pluralistic theories say. ${ }^{71}$

We will now turn to explore if and how the Guiding Principles on Business and Human Rights and its concepts have been invoked in the local level, both by State authorities and actors and by transnational corporations operating therein.

70 Fabián Novak Talavera, Second Report: Corporate Social Responsibility in the Area of Human Rights and the Environment in the Americas, OEA/Ser.Q, CJI/doc.449/14 rev. 1, 84th Regular Session, Brazil, 11 March 2014, pp. 5-6.

71 Nicolás Carrillo Santarelli, La legitimidad como elemento crucial de la efectividad de pronunciamientos de la Corte Interamericana de Derechos Humanos ante casos complejos y desafíos regionales, 18 Revista General de Derecho Público Comparado, 9, 12-13 (2015). 


\section{THE INFLUENCE OF THE GUIDING PRINCIPES ON BUSINESS AND HUMAN RIGHTS IN THE ACTIONS AND MINDSET OF STATES IN THE AMERICAS AND BUSINESSES OPERATING THEREIN}

This section will explore only the most salient examples of how the Guiding Principles on Business and Human Rights and their concepts have been invoked at the State level by its authorities: judicial ones in their case law; legislative ones when enacting certain peace, and other regulations or asking for investigations; and central ones in the adoption of National Action Plans. It will be noted how they have also been referred to by transnational corporations themselves that operate in the Americas, among others.

The main idea that can be gleaned from these examples is that references made to the UNGPs are sometimes explained because authorities that used to protect from non-state abuses before the 2011 adoption of the Principles now invoke them to reinforce and strengthen their arguments. Additionally, some new initiatives, such as efforts to investigate corporate complicity with the Argentinian dictatorship, may have been propelled by awareness raised by the UNGPs and other standards. As to corporations, they may rely on the UNGPs out of an honest commitment or concern, but may possibly also do so to a lesser or larger extent with the aim of improving their public image and avoid or deflect criticism to their operations, and thus of avoiding market or commercial losses or sanctions. ${ }^{72}$

72 August Reinisch, op. cit., at 52; Alexandra Gatto, Corporate Social Responsibility in the External Relations of the EU, 24 Yearbook of European Law, 431 (2005). 
The use and invocation of the Guiding Principles on Business and Human Rights by judicial authorities in the Americas

While it has been noted in other jurisdictions in the Americas, such as the Mexican one, that their judicial authorities can refer to the Guiding Principles ${ }^{73}$ and that human rights must be protected from negative corporate impact -as the Mexican National Human Rights Commission pointed out ${ }^{74}$ the UNGPs have been expressly referred to by the Colombian Constitutional Court, as discussed below. Furthermore, in their case law, judicial bodies such as the Argentinian Supreme Court have protected human rights when they collided with norms protecting some corporate interests. ${ }^{75}$ Thus, some judiciaries in the region have been proactive in the protection of human rights from corporate abuses.

Just as it happened in the Inter-American Human Rights System, before the adoption of the UNGPs, in Colombia there was a tradition of permitting the use of remedies on the protection of fundamental rights against non-state actors, without the State necessarily being a respondent. This has been allowed when individuals are placed in a so-called "situation of helplessness" or vulnerability in relation to them. In this sense, Colombian Decree 2591 of 1991 permits the use of the tutela remedy against private parties when they are in charge of supplying public services, when they exercise public functions, when they threaten certain rights, or when the applicants are in a situation of helplessness or subordination in relation to them. Such possibility was defined and confirmed, among others, in judgments T-254/93 and T-202/12 of the Colombian Constitutional Court, which has

73 Laura Adriana Esparza García, Los principios rectores sobre las empresas y derechos humanos: su aplicación como instrumento soft law (2014). https://www.academia.edu/21569124/ LOS_PRINCIPIOS_RECTORES_SOBRE_LAS_EMPRESAS_Y_DERECHOS_HUMANOS_SU_APLICACIÓN_COMO_INSTRUMENT̄O_SOFT_LAW $\overline{\text { Inauto }}=$ download

74 Comisión Nacional de Derechos Humanos (México), Destaca Ombudsman nacional responsabilidad de las empresas para generar mecanismos que remedien afectaciones a derechos humanos, derivadas de su propia actividad, Press Release CGCP/097/16 (2016). http://www. cndh.org.mx/sites/all/doc/Comunicados/2016/Com_2016_097.pdf

75 UNDP and Global Compact (Red Pacto Mundial Argentina), Guia de derechos humanos para empresas: proteger, respetar y remediar: todos ganamos, 13 (2012). http://pactoglobal.org.ar/ wp-content/uploads/2015/02/Gu--a_Empresas-y-Derechos-Humanos.pdf 
defined that situation of helplessness as one in which individuals are unable to defend themselves physically or legally from aggressions, as explained in those decisions. Hence, victims have been able to invoke the tutela remedy against corporations under some circumstances, and have done so both before and after the adoption of the UNGPs, which have actually been cited in decisions of the Court.

A noteworthy decision that permitted the use of the tutela remedy when individuals are in a "situation of helplessness" precisely in relation to businesses is the Colombian Constitutional Court's judgment T-732/16. The judgment expressly referred to the Guiding Principles on Business and Human Rights, describing their history and their main components; when describing the 'respect' pillar, the Court properly highlighted the relevance of the notion of due diligence. Finding that the corporate activity it studied in that case had a negative environmental and housing impact, the Court said that while companies do not have the same obligations that States do, they are under a "duty to respect rights and not cause harm." Given the obligations that the State had, the Constitutional Court gave State authorities different orders aimed at the protection of the applicant, and also "urged the company to undertake preventative measures in relation to the possible harm that it may cause to houses that are found in the same situation as that of the applicant." 76

This is one judgment that exemplifies how domestic actors can internalize and appropriate the language of the UNGPs and use discourses referring to them in ways that assume that corporations do have human rights obligations, and that permit asking businesses to do -or refrain from doing something. The case study also confirms how reliance on the Guiding Principles does not necessarily entail or require the regulation of completely new actions, being it sometimes sufficient for authorities to conduct already existing powers and competences in ways that expressly refer to business and human rights problematics and standards.

76 Colombian Constitutional Court, Judgment T-732/16, 19 December 2016. 
Another decision of the same Court, judgment T-657/13, also referred to the UNGPs, and likewise alluded to the idea (related to the respect pillar) that businesses must prevent or diminish the negative human rights impact of their operations, by citing Principle 13 of the UNGPs. ${ }^{77}$

\section{The Guiding Principles as the inspiration of developments} of legislative State action and policies in the Americas

While there is still much to be done, being it important for different jurisdictions to address the subject matter in a more express and proactive way, it can be said that in addition to judicial action, Latin American States have taken other important steps in relation to business and human rights aspects and corporate complicity in serious abuses. Notable examples include a law enacted in 2015 by the Argentinian National Congress ordering the creation of a Bicameral Commission for Identifying Economic Complicity during the Last Military Dictatorship, ${ }^{78}$ the goal of which was:

[...] preparing a report with participation of civil society regarding the consequences of the economic, monetary, industrial, commercial and financial policies adopted by the last civilian-military dictatorship and identify the economic and technical actors that contributed to and/or benefited from the dictatorship. ${ }^{79}$

Another remarkable step was the amended Final Agreement for the Termination of the Conflict and the Building of a Stable and Lasting Peace between the Colombian Government and the FARC guerrilla, which envisages a System of Truth, Justice, Reparation, and Non-repetition in which all direct and indirect

77 Colombian Constitutional Court, Judgment T-657/13, 23 September 2013.

78 See: Sancionan ley para crear una bicameral que investigue la complicidad de las empresas con la dictadura (2015). http://www.parlamentario.com/noticia-87728.html

79 Centro de Estudios Legales y Sociales, Report from the Center for Legal and Social Studies (CELS), Executive Summary, Evaluation of Compliance with the International Covenant on Civil and Political Rights in Argentina in the Framework of the Submission of the Fifth Periodic Report before the Human Rights Committee, $117^{\circ}$ Period of Sessions, http://tbinternet.ohchr. org/Treaties/CCPR/Shared\%20Documents/ARG/INT_CCPR_CSS_ARG_24355_E.pdf 
participants in the Colombian armed conflict that were involved in serious violations of human rights and international humanitarian law ought to recognize their responsibility. They are also subject to the (transitional) justice component of the agreement. ${ }^{80}$ As argued elsewhere, such broad definition of participants likely encompasses, among others, those businesses that either perpetrated or were complicit to said abuses. ${ }^{81}$ This is an important step, insofar as transition to peace does require the accountability of everyone, no matter what their legal and ontological identity is, that participated in serious abuses. The underlying rationales of both the Argentinian and Colombian initiatives seem to share a desire to precisely bring about accountability and the revelation of the truth surrounding violations during periods in which their populations suffered heinous abuses, in some of which businesses regrettably participated and disregarded the dignity that all individuals have.

Those two measures were intended to address situations of crisis. Yet, National Action Plans are other important tools that seek to bring about compliance with the UNGPs at all times and have been considered to have importance in relation to the possibility of effectively protecting human rights and connected values. ${ }^{82}$ To the date of writing this article, the only Latin American State to have already adopted a National Action Plan was Colombia, with four others (Argentina, Mexico, Guatemala, and Chile) undertaking drafting processes to elaborate theirs. ${ }^{83}$

As to the Colombian Plan, it introduces general objectives and specific purposes to bring about the effectiveness of the three pil-

80 Acuerdo final para la terminación del conflicto y la construcción de una paz estable y duradera, 24 November 2016.

81 Nicolás Carrillo Santarelli, No ignoremos la complicidad empresarial en el conflicto armado, El Espectador, Colombia 2020, 31 August 2016. http://colombia2020.elespectador.com/justicia/ no-ignoremos-la-complicidad-empresarial-en-el-conflicto-armado

82 United Nations Working Group on Business and Human Rights, Guidance on National Action Plans on Business and Human Rights, Version 1.0, 2014. http://www.ohchr.org/Documents/ Issues/Business/UNWG_\%20NAPGuidance.pdf; European Parliament, Study: Implementation of the UN Guiding Principles on Business and Human Rights, 2017, http://www.europarl.europa. eu/RegData/etudes/STUD/2017/578031/EXPO_STU(2017)578031_EN.pdf

83 Sources: http://www.ohchr.org/EN/Issues/Business/Pages/NationalActionPlans.aspx; https://business-humanrights.org/en/un-guiding-principles/implementation-tools-examples/ implementation-by-governments/by-type-of-initiative/national-action-plans 
lars of the UNGPs. In regards to State protection, it encourages coordination between State agents and bodies, promoting and supporting private initiatives of observance of the UNGPs, and fostering civil society participation. Concerning the dimension of the corporate respect of human rights, the Plan promotes fostering a corporate culture that is respectful of human rights, asking for the integration of social responsibility considerations and providing incentives to companies that adopt the UNGP standards. Finally, it also endeavors to promote and supervise the effectiveness of both judicial and non-judicial remedies. ${ }^{84}$

This Plan shows that States in the region and elsewhere may devise specific incentives and strategies that seek to bring about compliance with the Guiding Principles through different strategies and in a holistic manner, not exclusively through one set of actions. After all, multiple strategies, and not only judicial action (necessary though they are), are important for human rights to be respected by corporations and other non-state actors. Moreover, National Action Plans have been specifically motivated by the UNGPs themselves. Thus, in addition to setting forth -codifying and developing the shared principles of the Guiding Principles and other domestic and international standards (such as the OECD Guidelines for Multinational Enterprises) ${ }^{85}$ their adoption can also lead to new actions that can help to address business and human rights problems as those faced in the Americas.

84 Presidencia de la República de Colombia, Consejería de Derechos Humanos. 'Colombia Avanza': hacia la construcción de un Plan Nacional de acción sobre empresas y derechos humanos, Cartagena de Indias 27 de octubre de 2015.

85 Some of those standards are certainly mentioned in the following official document on the implementation of the Colombian National Action Plan: Presidencia de la República de Colombia, Plan nacional de acción en derechos humanos y empresa: informe de avances en la implementación, 37-38. http://www.derechoshumanos.gov.co/lineasestrategicas/empresa/ Documents/170331-informe\%20ddhh-empresas.pdf 
Reference to the Guiding Principles in the codes of conduct of corporations that operate in the Americas

Finally, it must be noted that some corporations that operate in the Americas have adopted codes of conduct or other statements that expressly mention and endorse the Guiding Principles on Human Rights. In this sense, companies have been prompted to publicly commit to them. The way in which this is done:

"[d]oes not necessarily need to be a stand-alone statement, but could be integrated into existing corporate statements and business partner codes of conduct. The statement must be embedded from the top of the company through all its functions, and be reflected in operational policies and processes as necessary. ${ }^{86}$

Needless to say, such incorporation attests to the importance attached to the UNGPs nowadays. Regardless of the true intentions of the companies doing this, the inclusion of the Principles in their codes of conduct and reference to them in their statements is important and can generate two different effects. Firstly, by virtue of socialization, acculturation, internalization, and other processes, corporate culture, which is crucial and thus worthy of being paid attention to (as Ruggie did), ${ }^{87}$ may end up being at least partly guided by it, with the subsequent impact this can have on operations. This is more likely to happen when the staff of companies internalize the message of the UNGPs and develop and implement their own commitments towards them, and also if units entrusted with human rights issues are constituted in the corporate structure and have certain relative autonomy, as liberal and bureaucracy theories suggest in regards to other subjects. ${ }^{88}$

86 United Nations, Frequently asked questions about the Guiding Principles on Business and Human Rights, New York and Geneva, 2014, at 27, http://www.ohchr.org/Documents/Publications/FAQ_PrinciplesBussinessHR.pdf

87 Human Rights Council, Protect, Respect, and Remedy: a Framework for Business and Human Rights. Report of the Special Representative of the Secretary-General on the issue of human rights and transnational corporations and other business enterprises, John Ruggie, $A / H R C / 8 / 5$, 7 April 2008, paras. 27, 29-32, 105.

88 Michael W. Bauer and Jörn Ege, Bureaucratic autonomy of international organizations' secre- 
Secondly, as has been argued in the International Law Association, codes of conduct and "voluntary" guidelines, even when they do not produce direct legal effects, may indirectly generate them by virtue of the operation of the principle of good faith and related doctrines and institutions, such as that of estoppel. It may also happen that States ask companies to abide by their commitments -e.g. in consumer protection norms. Concerning these ideas, what the International Law Association said was the following:

Many non-State actors, e.g. corporations and armed opposition groups, commit themselves to upholding international law. However, they tend to do so as a matter of policy/soft law than as a matter of hard law. In so doing, they may avoid legal accountability. There may nevertheless be doctrines and principles that could be used to harden these soft commitments into hard law (duty of care/negligence/corporate organization/legitimate expectations/good faith/unilateral act...). ${ }^{89}$ (original underscored).

Among the companies operating in the Americas that have adopted codes of conduct mentioning the UNGPs it is possible to mention Ericsson, whose Code of Business Ethics (Código de Ética Empresarial), both in its English and Spanish versions, expressly indicates the following:

We are committed to implementing the UN Guiding Principles for Business and Human Rights throughout our business operations. We strive to ensure that we are not complicit in any human rights abuses. We shall, in all contexts, seek ways to honor the principles of internationally recognized human rights, even when faced with conflicting requirements..$^{90}$

Other companies that also expressly refer to the UNGPs are Shell ("Our human rights approach is informed by the UN

tariats, 23 Journal of European Public Policy (2016); Anne-Marie Slaughter and Thomas Hale, International Relations, Principal Theories, Max Planck Encyclopedia of Public International Law (2013).

89 International Law Association, Non-State Actors Committee, Report: Preliminary issues for the ILA Conference in Rio de Janeiro, August 2008, 2008, at 3.

90 Ericsson, Code of Business Ethics. https://www.ericsson.com/assets/local/about-ericsson/ corporate-governance/documents/code-of-business-ethics/ericsson-cobe-2015-en.pdf(English version) and https://www.ericsson.com/assets/local/about-ericsson/corporate-governance/ documents/code-of-business-ethics/ericsson-cobe-2015-es.pdf (Spanish version). 
Guiding Principles on Business and Human Rights and applies to all of our employees and contractors") ${ }^{91}$ and Coca-Cola, whose Human Rights Policy also mentions that its partners are encouraged to also observe them. The latter Policy indicates that it:

[I]s guided by international human rights principles encompassed in the Universal Declaration of Human Rights, the International Labor Organization's Declaration on Fundamental Principles and Rights at Work, the United Nations Global Compact and the United Nations Guiding Principles on Business and Human Rights [...] The Human Rights Policy applies to The Coca-Cola Company, the entities that it owns, the entities in which it holds a majority interest, and the facilities that it manages. The Company is committed to working with and encouraging our bottling partners to uphold the principles in this Policy and to adopt similar policies within their businesses. The Supplier Guiding Principles applies to our bottling partners and our suppliers, and are aligned with the expectations and commitments of this Policy. ${ }^{92}$

Another quite interesting example is that of Telefónica, which provides phone services in the Americas, among others, and indicates that there has been a progressive change triggered by the Guiding Principles on Business and Human Rights, which reflect the current consensus and serve as a national and international benchmark ${ }^{93}$-echoing some of the ideas presented in this article. Its Human Rights Commitment (Derechos Humanos: compromiso) says that the company is a member of the Global Compact, which it observes, and that it respects the UNGPs ("respetamos el marco establecido en los Principios Rectores de las Naciones Unidas sobre Empresas y Derechos Humanos.” $)^{94}$

91 Source: http://www.shell.com/sustainability/transparency/human-rights.html

92 Source: http://www.coca-colacompany.com/content/dam/journey/us/en/private/fileassets/ pdf/2014/11/human-rights-policy-pdf-english.pdf

93 Source: https://www.telefonica.com/en/web/negocio-responsable/nuestros-compromisos/ derechos-humanos/introduccion ("Reflejo de ello es el progresivo establecimiento de marcos normativos nacionales e internacionales, el aumento de los juicios a empresas por abusos y la creciente preocupación de los grupos de interés afectados (ciudadanos, organizaciones sin ánimo de lucro, inversores, etc.). El detonante de este cambio han sido los Principios Rectores sobre Empresa y Derechos Humanos, hasta la fecha la máxima expresión del consenso internacional existente en esta materia y marco de referencia de otros estándares de sostenibilidad, tanto nacionales como internacionales."

94 Source: https://www.telefonica.com/documents/364672/452644/TELF_Derechos-Humanos_ compromiso_ESP-Infancia.pdf/5b559261-006e-483c-bead-14771200b511 
Other companies have issued human rights statements and commitments without referring to the UNGPs but to other pertinent standards. Yet, they do sometimes mention concepts found in the Guiding Principles, without expressly citing them. Those statements can be found in the useful webpage of the Business \& Human Rights Resource Centre. ${ }^{55}$ Some notable examples of such companies, that operate in the Americas, include Siemens, whose 2009 Business Conduct Guidelines refer to the respect of human rights and mention the expectation that its employees, suppliers, and business partners observe the Universal Declaration of Human Rights (curiously, an instrument cited by many corporate statements that has also been considered to impose implied obligations on non-state actors), ${ }^{96}$ the OECD Guidelines for Multinational Enterprises, the ILO (International Labor Organization) Tripartite Declaration of Principles concerning Multinational Enterprises and Social Policy, the ILO Declaration on Fundamental Principles and Rights at work, and the UN Convention Against Corruption, among others ${ }^{97}$-needless to say given how those Guidelines were adopted prior to 2011, the UNGPs could not be mentioned. Other companies whose statements refer to some of those or other human rights standards are PepsiCo (also citing the Universal Declaration), ${ }^{98}$ Gas Natural Fenosa, whose Human Rights Policy (Política de Derechos Humanos de Gas Natural Fenosa) mentions the Global Compact, but also fails to cite the UNGPs; ${ }^{99}$ Johnson \& Johnson's Statement on Human Rights, ${ }^{100}$ McDonald's Standards of Business Con-

95 Source: https://business-humanrights.org/en/company-policy-statements-on-human-rights

96 Jordan J. Paust, The Other Side of Right: Private Duties Under Human Rights Law, 5 Harvard Human Rights Journal, 51-54 (1992); International Centre for Settlement of Investment Disputes, Urbaser S.A. and Consorcio de Aguas Bilbao Bizkaia, Bilbao Biskaia Ur Partzuergoa Vs. The Argentine Republic, ICSID Case N. ${ }^{\circ}$ ARB/07/26, Award, 8 December 2016.

97 Source: https://www.siemens.com/about/sustainability/pool/cr-framework/business_conduct_guidelines_e.pdf

98 Source: https://www.pepsico.com/Assets/Download/CodeOfConduct/English_GCOC_2014. pdf

99 Source: http://portal.gasnatural.com/archivos/corp/Pol\%C3\%ADtica_DDHH_Español.pdf

100 Source: https://www.jnj.com/about-jnj/company-statements/statement-on-human-rights 
duct; ${ }^{101}$ and Nestlé's Corporate Business Principles. ${ }^{102}$ Securitas' Code of Conduct, in turn, undertakes "support and respect for fundamental human rights and recognises our responsibility to observe those rights when we conduct our business." 103 Repsol, interestingly, refers to concepts found in the UNGPs as that of due diligence in its Human Rights Policy. ${ }^{104}$

Finally, it is important to stress that there is still much to be done. Firstly, it does not suffice for companies to refer to the UNGPs or other standards, because, as logic suggests, commitments must be effective in practice, and it does not suffice for them to be formally adopted. ${ }^{105}$ Furthermore, in 2016 the United Nations Working Group on Business and Human Rights pointed out, after a visit to Mexico, that several companies it examined participate in the Global Compact, indicate that they will observe its principles, and additionally present annual sustainability reports, but yet failed to demonstrate if and how those respective companies integrated a principle of the UNGPs as important as that of due diligence ${ }^{\mathbf{1 0 6}}$ in their respective operations. ${ }^{107}$

101 Source: https://www.mcdonalds.com/dam/AboutMcDonalds/Investors/9497_SBC_International_EN-US\%20v2\%20final\%20061311.pdf

102 Source: http://www.nestle.com/asset-library/Documents/Library/Documents/Corporate_Governance/Corporate-Business-Principles-EN.pdf

103 Source: http://www.securitas.com.ro/globalassets/egypt/files/securitas-code-of-conduct.pdf

104 https://www.repsol.energy/en/sustainability/policies/human-rights-policy/index.cshtml

105 I/A Court H.R., Case of the Kaliñ a and Lokono Peoples v. Suriname. Merits, Reparations, and Costs. Judgment of November 25, 2015. Series C N. ${ }^{\circ} 309$, paras. 237-241.

106 United Nations, Guiding Principles on Business and Human Rights: Implementing the United Nations "Protect, Respect, and Remedy" Framework, 2011, Principles 15, 17 through 22.

107 United Nations Office of the High Commissioner for Human Rights, Declaración del Grupo de trabajo de Naciones Unidas sobre empresas y derechos humanos al final de su visita a México, Mexico City, 7 September 2016. http://hchr.org.mx/images/doc_pub/20160907_EOM_Mexico_FINAL_SPA.pdf 


\section{CONCLUSIONS}

Protecting individuals from all abuses and activities with a negative impact on the enjoyment of their human rights is an ethical imperative, which can be accommodated in international and domestic law, so much so that even recent foreign investment awards have accepted the existence of implied corporate human rights responsibilities. ${ }^{108}$ Yet, there are many specific legal problems that are still being debated, ranging from issues of extraterritorial jurisdiction to whether businesses have any direct international human rights obligations, and what their precise scope is.

Given the problems faced in the Americas in terms of corporate abuses, it is unsurprising that both regional bodies and State authorities have tried to provide either direct or indirect protection from them, ${ }^{109}$ as shown in sections II and III. By appropriating and handling the concepts and standards found in the Guiding Principles on Business and Human Rights, those participants may reinforce their own discourses and make them seem more appealing to interlocutors around the world.

More so, it may happen that in the course of their practice, those participants give certain specific content to some of the somewhat broad notions of the UNGPs - many human rights instruments have a certain latitude or vagueness in some respects ${ }^{110}$ which if it ends up being shared can generate a "common regional understanding," generating de facto lowest common denominators that can decrease the chances of there being gaps or disagreements in the region that corporations can take advantage of by relocating to other neighboring States with lower standards. Furthermore, this common understanding may be

108 International Centre for Settlement of Investment Disputes, op. cit., paras. 1159, 1196, 1199.

109 On direct and indirect responses to non-state human rights violations, see: John H. Knox, Horizontal Human Rights Law, 102 American Journal of International Law (2008).

110 Eric A. Posner, The Twilight of Human Rights Law, 47, 86-87, 95-96, 103, 121 (Oxford University Press, Oxford, 2014). 
later adopted, to a greater or lesser extent, by participants from other regions, and even in the United Nations or general custom.

Furthermore, transnational actors operating in the region will be hard pressed to adjust their practice and discourses to the prevalent understanding of participants and authorities in the Americas, lest they expose themselves to sanctions or negative commercial repercussions. An additional incentive to undertake those commitments is the zeitgeist and social pressure to observe human rights standards generated by the adoption of the UNGPs -expressly referred to or implicitly endorsing core tenets in local and regional standards and decisions given their widespread acceptance as a contemporary canon of normative expectations on businesses. This does not necessarily suggest that the principles are always adopted out of the fear of negative economic and other repercussions, since they may also be internalized because of acculturation processes or the appropriation of their concepts by the agents of companies due to ethical or other reasons, consciously or not.

Furthermore, internalization does not necessarily reveal an express appropriation of the UNGPs as such -it may be that their notions, as due diligence and others are internalized without necessary reference to the Principles, whose success partly lies in making some basic concepts known by all. In any case, by adopting statements on human rights commitments, either referring to the Guiding Principles or to their standards and concepts, businesses operating in the Americas may end up internalizing or realizing that they are required to adjust to the way in which the UNGPs are conceived generally and in the Americas -when regional practice fills the content of broad standards in the way that they are understood in the region by influential authorities and bodies.

Altogether, the regional initiatives and understandings of the UNGPs and other standards that achieve consensus in the field may contribute to making sure that law serves human dignity 


\section{more than profit and other considerations, which is a legitimacy imperative. ${ }^{111}$}

111 Concurring Opinion of Judge A.A. Cançado Trindade to: I/A Court H.R., Juridical Condition and Human Rights of the Child. Advisory Opinion OC-17/02 of August 28, 2002. Series A N. ${ }^{17}$, paras. 13, 19; Myres S. McDougal and Harold D. Lasswell, The Identification and Appraisal of Diverse Systems of Public Order, op. cit., 5-6, 11; Steven R. Ratner, The Thin Justice of International Law: A Moral Reckoning of the Law of Nations, 65 (Oxford University Press, Oxford, 2015). 


\section{BIBLIOGRAPHY}

\section{Instruments}

Acuerdo final para la terminación del conflicto y la construcción de una paz estable y duradera, 24 November 2016.

Colombia avanza: derechos humanos y empresa. Plan de Acción de Derechos Humanos y Empresas.

Memorandum of Understanding between the General Secretariat of the Organization of American States through the Inter-American Commission on Human Rights and the Danish Institute for Human Rights.

United Nations, Guiding Principles on Business and Human Rights: Implementing the United Nations "Protect, Respect and Remedy" Framework, 2011.

\section{Doctrine}

Alston, Philip, The "Not-a-Cat" Syndrome: Can the International Human Rights Regime Accommodate Non-State Actors?, in Non-State Actors and Human Rights (Philip Alston, ed., Oxford University Press, Oxford, 2005).

Bauer, Michael W. and Ege, Jörn, Bureaucratic autonomy of international organizations' secretariats, 23 Journal of European Public Policy (2016).

Becker Lorca, Arnulf, Mestizo International Law (Cambridge University Press, Cambridge, 2014).

Brotóns, Antonio Remiro et al., Derecho internacional (Tirant Lo Blanch, Valencia, 2007).

Capie, David, Influencing Armed Groups: Are there Lessons to Be Drawn from Socialization Literature?, in Exploring Criteria \& Conditions for Engaging Armed Non-State Actors to Respect Humanitarian Law \& Human Rights Law, Conference Report, Geneva, 4-5 June 2007 (Geneva Call, Geneva, 2008).

Carrillo Santarelli, Nicolás, Inconvenient and Unnecessary? A Defense of Direct International Human Rights Obligations of (All) Corporations, in The Future of Business and Human Rights: Theoretical and Practical Considerations for a UN Treaty (Jernej Letnar Černič and Nicolás Carrillo-Santarelli, eds., Intersentia, Cambridge Forthcoming, 2017).

Carrillo Santarelli, Nicolás, La influencia "artística" de las emociones y la empatía en el contenido, la interpretación y la efectividad del derecho internacional, XVII Anuario Mexicano de Derecho Internacional (2017).

Carrillo Santarelli, Nicolás, La legitimidad como elemento crucial de la efectividad de pronunciamientos de la Corte Interamericana de Derechos Humanos ante casos complejos y desafíos regionales, 18 Revista General de Derecho Público Comparado, 9, 12-13 (2015).

Deva, Surya, 'What if the Roadblock Continues?': Alternatives Ways to Getting a Business and Human Rights Treaty, in The Future of Business and Human Rights: 
Theoretical and Practical Considerations for a UN Treaty (Jernej Letnar Černič and Nicolás Carrillo-Santarelli, eds., Intersentia, Cambridge, Forthcoming 2017).

Esparza García, Laura Adriana, Los principios rectores sobre las empresas y derechos humanos: su aplicación como instrumento soft law (2014).

European Parliament, Study: Implementation of the UN Guiding Principles on Business and Human Rights, 2017.

Gatto, Alexandra, Corporate Social Responsibility in the External Relations of the EU, 24 Yearbook of European Law, 431 (2005).

Geisinger, Alex and Ashley Stein, Michael, A Theory of Expressive International Law, 60 Vanderbilt Law Review (2000).

Goodman Ryan and Jinks, Derek, Incomplete Internalization and Compliance with Human Rights Law, 19 European Journal of International Law (2008).

Higgins, Rosalyn, Problems \& Process: International Law and How We Use it (Oxford University Press, Oxford, 2004).

Hongju Koh, Harold, Internalization through Socialization, 54 Duke Law Journal (2005).

Hongju Koh, Harold, Why Do Nations Obey International Law?, 106 The Yale Law Journal (1997).

International Law Association, Non-State Actors Committee, Report: Preliminary issues for the ILA Conference in Rio de Janeiro, August 2008, 2008.

Klabbers, Jan, International Law (Cambridge University Press, Cambridge, 2013).

Kittrie, Orde F., Lawfare: Law as a Weapon of War (Oxford University Press, Oxford, 2016).

Knox, John H., The Human Rights Council Endorses "Guiding Principles” for Corporations, 15 ASIL Insights, 2011.

Knox, John H., Horizontal Human Rights Law, 102 American Journal of International Law (2008).

$\mathrm{Ku}$, Julian, The Unattractive Question is Back: SCOTUS (Again) Considers Corporate Liability Under the Alien Tort Statute, Opinio Juris (2017).

Lasswell, Harold D. and McDougal, Myres S., Jurisprudence in Policy-Oriented Perspective, XIX University of Florida Law Review (1966-67).

Lixinski, Lucas, Treaty Interpretation by the Inter-American Court of Human Rights: Expansionism at the Service of the Unity of International Law, 21 European Journal of International Law (2010).

McAdams, Richard H., The Expressive Powers of Law: Theories and Limits (Harvard University Press, Harvard, 2015).

McDougal, Myres S. and Lasswell, Harold D., The Identification and Appraisal of Diverse Systems of Public Order, 53 The American Journal of International Law (1959).

Paust, Jordan J., The Other Side of Right: Private Duties Under Human Rights Law, 5 Harvard Human Rights Journal, 51-54 (1992).

Posner, Eric A., The Twilight of Human Rights Law (Oxford University Press, Oxford, 2014). 
Pasqualucci, Jo M., The Practice and Procedure of the Inter-American Court of Human Rights, 263 (2nd ed., Cambridge University Press, Cambridge, 2013).

Ratner, Steven R., The Thin Justice of International Law: A Moral Reckoning of the Law of Nations (Oxford University Press, Oxford, 2015).

Reinisch, August, The Changing International Legal Framework for Dealing with NonState Actors, in Non-State Actors and Human Rights (Philip Alston, ed., Oxford University Press, Oxford, 2005).

Ruggie, John G., Kiobel and Corporate Social Responsibility: An Issues Brief by John G. Ruggie, 2012.

Slaughter, Anne-Marie and Hale, Thomas, International Relations, Principal Theories, Max Planck Encyclopedia of Public International Law (2013).

Van Ho, Tara L. "Say You'll Remember Me:” In Defense of a Traditional State-Centric Approach to the Treaty", in The Future of Business and Human Rights: Theoretical and Practical Considerations for a UN Treaty (Jernej Letnar Černič and Nicolás Carrillo-Santarelli, eds., Intersentia, Cambridge, Forthcoming 2017).

UNDP and Global Compact (Red Pacto Mundial Argentina), Guía de derechos humanos para empresas: Proteger, Respetar y Remediar: Todos Ganamos, 13 (2012).

\section{Reports and Press Releases}

Centro de Estudios Legales y Sociales, Report from the Center for Legal and Social Studies (CELS), Executive Summary, Evaluation of Compliance with the International Covenant on Civil and Political Rights in Argentina in the Framework of the Submission of the Fifth Periodic Report before the Human Rights Committee, $117^{\circ}$ Period of Sessions.

Comisión Nacional de Derechos Humanos (México), Destaca Ombudsman nacional responsabilidad de las empresas para generar mecanismos que remedien afectaciones a derechos humanos, derivadas de su propia actividad, Press Release CGCP/097/16 (2016).

Human Rights Council, Elaboration of an international legally binding instrument on transnational corporations and other business enterprises with respect to human rights, A/HRC/26/L.22/Rev.1, 25 June 2014.

Human Rights Council, Protect, Respect and Remedy: a Framework for Business and Human Rights. Report of the Special Representative of the Secretary-General on the issue of human rights and transnational corporations and other business enterprises, John Ruggie, $A / H R C / 8 / 5,7$ April 2008.

Human Rights Council, Report of the Working Group on the issue of human rights and transnational corporations and other business enterprises on the "Regional consultation for Latin America and the Caribbean on public policy for the implementation of the United Nations Guiding Principles on Business and Human Rights in the Framework of the 2030 Agenda on Sustainable Development", A/HRC/32/45/ Add.4, 9 June 2016.

Human Rights Council, Report on the first session of the open-ended intergovernmental 
working group on transnational corporations and other business enterprises with respect to human rights, with the mandate of elaborating an internationally legally binding instrument, $A / H R C / 31 / 50,5$ February 2016.

Inter-American Commission on Human Rights, Criminalization of Human Rights Defenders, OEA/Ser.L/V/II, Doc. 49/15, 31 December 2015.

Inter-American Commission on Human Rights, Human Mobility, Inter-American Standards, OEA/Ser.L/V/II, Doc. 46/15, 31 December 2015.

Inter-American Commission on Human Rights, Indigenous and Tribal Peoples' Rights over their Ancestral Lands and Natural Resources: Norms and Jurisprudence of the Inter-American Human Rights System, OEA/Ser.L/V/II, Doc. 56/09, 30 December 2009.

Inter-American Commission on Human Rights, Indigenous Peoples, Communities of African Descent, Extractive Industries, OEA/Ser.L/V/II, Doc. 47/15, 31 December 2015.

Inter-American Commission on Human Rights, Report on Terrorism and Human Rights, OEA/Ser.L/V/II.116, Doc. 5 rev. 1 corr., 22 October 2002.

Inter-American Commission on Human Rights, Situation of Human Rights in Guatemala, OEA/Ser.L/V/II. Doc. 43/15, 31 December 2015.

Inter-American Commission on Human Rights, Situation of Human Rights in Honduras, OEA/Ser.L/V/II, Doc. 42/15, 31 December 2015.

Inter-American Commission on Human Rights, The Human Rights Situation in Mexico, OEA/Ser.L/V/II, Doc. 44/15, 31 December 2015.

Inter-American Commission on Human Rights, Violence, Children and Organized Crime, OEA/Ser.L/V/II, Doc. 40/15, 11 November 2015.

Inter-American Commission on Human Rights, Report on the Situation of Human Rights in Ecuador, OEA/Ser.L/V/II.96, Doc. 10 rev. 1, 24 April 1997.

International Law Commission, Conclusions of the work of the Study Group on the Fragmentation of International Law: Difficulties arising from the Diversification and Expansion of International Law, Fifty-eighth session (2006).

International Law Commission, Draft articles on the responsibility of international organizations, with commentaries, sixty-third session, 2011.

Novak Talavera, Fabián, Second Report: Corporate Social Responsibility in the Area of Human Rights and the Environment in the Americas, OEA/Ser.Q, CJI/doc.449/14 rev.1, 84th Regular Session, Brazil, 11 March 2014.

United Nations Commission on Human Rights, Working paper on human rights and non-State actors submitted by Gáspár Biró and Antoanella-Iulia Motoc, E/CN.4/ Sub.2/2005/40, 11 July 2005.

United Nations Office of the High Commissioner for Human Rights, Introductory training on to the Guiding Principles on Business and Human Rights, Second Annual Forum on Business and Human Rights, 2 December 2013.

United Nations Office of the High Commissioner for Human Rights, Declaración del Grupo de trabajo de Naciones Unidas sobre empresas y derechos humanos al final de su visita a México, Mexico City, 7 September 2016. 
United Nations Working Group on Business and Human Rights, Guidance on National Action Plans on Business and Human Rights, Version 1.0, 2014.

United Nations Working Group on Business and Human Rights, The UN Guiding Principles on Business and Human Rights: An Introduction.

United Nations, Frequently asked questions about the Guiding Principles on Business and Human Rights, New York and Geneva, 2014.

United Nations, The UN "Protect, Respect and Remedy" Framework for Business and Human Rights, 2010.

XXVI Ordinary Session of the Human Rights Council, Statement of Archbishop Silvano M. Tomasi, Permanent Observer of the Holy See to the United Nations and Specialized Agencies in Geneva, 11 June 2014.

\section{Case Law and Votes}

Colombian Constitutional Court, Plenary Chamber, Judgment T-657/13, 23, Case file T-3922869, parties: Junta Directiva del Consejo Comunitario de Mulaló versus Ministry of the Environment and Sustainable Development, Interior Ministry, INVIAS, D.I.S. S.A- EDL LTDA Consortium. Judge Rapporteur: María Victoria Calle Correa.

Colombian Constitutional Court, Plenary Chamber, Judgment T-732/16, 19, Case file T-5.357.971, parties: José Eliécer Díaz Bohórquez versus Ocensa and Boyacá Lands Consortium. Judge-Rapporteur: Gloria Stella Ortiz Delgado.

Committee on Economic, Social and Cultural Rights, General Comment on State Obligations under the International Covenant on Economic, Social and Cultural Rights in the Context of Business Activities: Draft prepared by Olivier De Schutter and Zdzislaw Kedzia, Rapporteurs, E/C.12/60/R.1, 17 October 2016.

Committee on Economic, Social and Cultural Rights, General comment No. 23 (2016) on the right to just and favourable conditions of work (article 7 of the International Covenant on Economic, Social and Cultural Rights), E/C.12/GC/23, 27 April 2016.

Committee on the Elimination of Discrimination against Women, General recommendation No. 34 (2016) on the rights of rural women, $C E D A W / C / G C / 34,7$ March 2016.

Concurring Opinion of Judge A.A. Cançado Trindade to: I/A Court H.R., Juridical Condition and Human Rights of the Child. Advisory Opinion OC-17/02 of August 28, 2002. Series A No.17.

Concurring Opinion of Judge A.A. Cançado Trindade to: I/A Court H.R., Matter of The Communities of Jiguamiandó and Curvaradó regarding Colombia. Provisional Measures. Order of the Inter-American Court of Human Rights of March 06, 2003.

Frontier Dispute, Judgment, I.C.J. Reports 1986, p. 554.

Inter-American Commission on Human Rights, Resolution $\mathrm{N}^{0} 12 / 85$, Case $\mathrm{N}^{\mathrm{o}} 7615$, Brazil, 5 March 1985.

International Centre for Settlement of Investment Disputes, Urbaser S.A. and Consorcio de Aguas Bilbao Bizkaia, Bilbao Biskaia Ur Partzuergoa Vs. The Argentine Republic, ICSID Case No. ARB/07/26, Award, 8 December 2016. 
I/A Court H.R., Case of Castillo Petruzzi et al. v. Peru. Merits, Reparations and Costs. Judgment of May 30, 1999. Series C No. 52.

I/A Court H.R., Case of González et al. ("Cotton Field”) v. Mexico. Preliminary Objection, Merits, Reparations and Costs. Judgment of November 16, 2009. Series C No. 205.

I/A Court H.R., Case of the "Street Children" (Villagrán-Morales et al.) v. Guatemala. Reparations and Costs. Judgment of May 26, 2001. Series C No. 77.

I/A Court H.R., Case of the Hacienda Brasil Verde Workers v. Brazil. Preliminary Objections, Merits, Reparations and Costs. Judgment of October 20, 2016. Series C No. 318.

I/A Court H.R., Case of the Kaliña and Lokono Peoples v. Suriname. Merits, Reparations and Costs. Judgment of November 25, 2015. Series C No. 309.

I/A Court H.R., Case of the Mayagna (Sumo) Awas Tingni Community v. Nicaragua. Merits, Reparations and Costs. Judgment of August 31, 2001. Series C No. 79.

I/A Court H.R., Case of the Miguel Castro Castro Prison v. Peru. Interpretation of the Judgment on Merits, Reparations and Costs. Judgment of August 2, 2008 Series C No. 181.

I/A Court H.R., Case of Velásquez Rodríguez v. Honduras. Merits. Judgment of July 29, 1988. Series C No. 4.

I/A Court H.R., Entitlement of legal entities to hold rights under the inter-american human rights system (Interpretation and scope of Article 1(2), in relation to Articles 1(2), 8, 11(2), 13, 16, 21, 24, 25, 29, 30, 44, 46 and 62(3) of the American Convention on Human Rights, as well as of Article 8(1)(A) and (B) of the Protocol of San Salvador). Advisory Opinion OC-22/16 of February 26, 2016. Series A No. 22.

I/A Court H.R., Interpretation of the American Declaration of the Rights and Duties of Man within the Framework of Article 64 of the American Convention on Human Rights. Advisory Opinion OC-10/89 of July 14,1989. Series A No.10.

I/A Court H.R., Juridical Condition and Human Rights of the Child. Advisory Opinion OC-17/02 of August 28, 2002. Series A No.17.

I/A Court H.R., Juridical Condition and Rights of the Undocumented Migrants. Advisory Opinion OC-18/03 of September 17, 2003. Series A No.18.

I/A Court H.R., Matter of The Communities of Jiguamiandó and Curvaradó regarding Colombia. Provisional Measures. Order of the Inter-American Court of Human Rights of March 06, 2003.

I/A Court H.R., Rights and guarantees of children in the context of migration and/or in need of international protection. Advisory Opinion OC-21/14 of August 19, 2014. Series A No.21.

North Sea Continental Shelf, Judgment, I.C.J. Reports 1969, p. 3.

United States Court of Appeals for the Second Circuit, Docket Nos. 06-4800-cv, 064876-cv, 17 September 2010.

United States Court of Appeals, Seventh Circuit, Boimah FLOMO, et al., PlaintiffsAppellants, v. FIRESTONE NATURAL RUBBER CO., LLC, Defendant-Appellee, N. $10-3675,11$ July 2011. 
